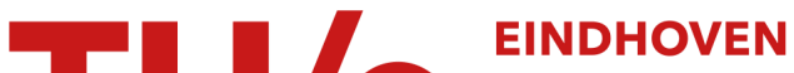 \\ UNIVERSITY OF \\ TECHNOLOGY
}

\section{Surface-modified electrodes (SME)}

Citation for published version (APA):

Schreurs, J. P. G. M., \& Barendrecht, E. (1984). Surface-modified electrodes (SME). Recueil des Travaux Chimiques des Pays-Bas, 103(7-8), 205-219. https://doi.org/10.1002/recl.19841030701

DOI:

10.1002/recl.19841030701

Document status and date:

Published: 01/01/1984

\section{Document Version:}

Publisher's PDF, also known as Version of Record (includes final page, issue and volume numbers)

\section{Please check the document version of this publication:}

- A submitted manuscript is the version of the article upon submission and before peer-review. There can be important differences between the submitted version and the official published version of record. People interested in the research are advised to contact the author for the final version of the publication, or visit the $\mathrm{DOI}$ to the publisher's website.

- The final author version and the galley proof are versions of the publication after peer review.

- The final published version features the final layout of the paper including the volume, issue and page numbers.

Link to publication

\section{General rights}

Copyright and moral rights for the publications made accessible in the public portal are retained by the authors and/or other copyright owners and it is a condition of accessing publications that users recognise and abide by the legal requirements associated with these rights.

- Users may download and print one copy of any publication from the public portal for the purpose of private study or research.

- You may not further distribute the material or use it for any profit-making activity or commercial gain

- You may freely distribute the URL identifying the publication in the public portal.

If the publication is distributed under the terms of Article 25fa of the Dutch Copyright Act, indicated by the "Taverne" license above, please follow below link for the End User Agreement:

www.tue.nl/taverne

Take down policy

If you believe that this document breaches copyright please contact us at:

openaccess@tue.nl

providing details and we will investigate your claim. 


\title{
Recueil Review
}

\author{
of progress in current research
}

\section{Surface-modified electrodes (SME)}

\author{
J. Schreurs and E. Barendrecht
}

Laboratory for Electrochemistry, Department of Chemical Engineering, Eindhoven University of Technology, P.O. Box 513, 5600 MB Eindhoven, The Netherlands (Received February 10th, 1984)

\begin{abstract}
This review deals with the literature (covered up to August 1983), the characterization and the applications of Surface-Modified Electrodes (SME). As a special class of SME's, the Enzyme-Modified Electrode (EME) is introduced.

Three types of modification procedures are distinguished; i.e. covalent modification, adsorption modification and polymer-film modification. A further subdivision is made for catalysts attached to the electrode surface directly or via a bridge molecule. The characterization of SME's is mainiy achieved via electrochemical techniques such as cyclic- and ac-voltammetry. This theory is briefly described and illustrated with some of our own results.

The name EME is used for a system in which the enzyme is immobilized at the electrode surface, such that direct electron transfer between electrode and enzyme becomes possible.

The last part of this review deals with the applications of SME's and EME's. Examples are given of some already realized and of some possible applications.
\end{abstract}

\section{Introduction}

The structure of the interface electrode/electrolyte. i.e. where the electrochemical reaction proceeds, is of decisive importance for an electrode reaction. If one were able to control the physical and chemical properties of this interface, then an improvement of reactivity, selectivity, etc., could be obtained. Moreover, access to new types of electrode reactions may become possible. Sometimes, the electrode reaction can be additionally influenced from the solution phase, e.g. by addition of an electrocatalyst to the solution. In general, however, this approach is rather unprofitable, since catalysis is usually required at the interface itself. This does not mean that the electrolyte side of the interface is of minor importance; it also structures the electrochemical double layer, and thus determines the course of the electrode reaction. Many electrode materials, such as metals, metal alloys, metal oxides, etc., have therefore been more or less successfully applied. However, in principle, it is unnecessary to change the bulk of the electrode material, since only the surface of the electode participates in the electrode reaction, provided that the bulk material merely functions as an electron conductor. The electrode reaction can therefore be affected by modification of the electrode surface via immobilization of an apt ("tailor-made") catalyst onto the surface [surface-modified electrode (SME)]. The desired functionality is thus fixed in the interface electrode-electrolyte.

Although it is somewhat less than a decade ago since Murray $^{1}$ and Miller $^{2}$ introduced the first preparation procedure (silanization) and also the first application (chiral induction) for modified electrodes, this type of surface treatment is now the focus of a number of electrocatalytic studies. Murray introduced the organosilicon reagent and initiated a series of publications on the preparation, characterization and electrocatalytic applications of modified electrodes. Kuwana ${ }^{4}$ was the first to

${ }^{1}$ P. R. Moses, L. Wier and R. W. Murray, Anal. Chem. 47, 1882 (1975).

2 B.F. Watkins, J. R. Behling, E. Kariv and L.L. Miller, J. Am. Chem. Soc. 97, 3549 (1975).

${ }^{3 a}$ B. E. Firth, L. L. Miller, M. Mitani, T. Rogers, J. Lennox and R. W. Murray, J. Am. Chem. Soc. 98, 8271 (1976).

${ }^{b}$ C. M. Elliot and R. W. Murray, Anal. Chem. 48, 1247 (1976).

c P. R. Moses and R. W. Murray, J. Am. Chem. Soc. 98, 7435 (1976).

d D.F. Untereker, J.C. Lennox, L. M. Wier, P. R. Moses and R. W. Murray, J. Electroanal. Chem. 81, 309 (1977).

- P. R. Moses and R. W. Murray, ibid. 77, 393 (1977).

f J. C. Lennox and R. W. Murray, ibid. 78, 395 (1977).

g J. R. Lenhard and R. W. Murray, ibid. 78, 195 (1977).

${ }^{h}$ L. M. Wier and R. W. Murray, ibid. 126, 617 (1979).

i J. C. Lennox and R. W. Murray, J. Am. Chem. Soc. 100, 3710 (1978).

j J.R. Lenhard and R. W. Murray, J. Am. Chem. Soc. 100, 5213 (1978).

k H. O. Finklea and R.W. Murray, J. Phys. Chem. 83, 353 (1979).

I J. R. Lenhard and R. W. Murray, J. Am. Chem. Soc. 100, 7870 (1978).

m J. R. Lenhard, R. Rocklin, H. Abruña, K. Willman, K. Kuo, R. Nowak and R. W. Murray, J. Electroanal, Chem. 94, 219 (1978).

${ }^{n} D . F$. Smith, K. Willman, K. Kuo and R. W. Murray, ibid. 95, 217 (1979).

- R. D. Rocklin and R.W. Murray, ibid. 100, 271 (1979)

p P. Daum and R. W. Murray, ibid. 103, 289 (1979).

4a J. F. Evans and T. Kuwana, Anal. Chem. 49, 1632 (1977).

${ }^{\mathrm{b}}$ J. F. Evans and T. Kuwana,ibid. 51, 358 (1979). 
use radio-frequency $(\mathrm{rf})$ plasma pretreatment for increasing the concentration of functional groups at carbon surfaces, while Anson ${ }^{5}$ and Laviron ${ }^{6}$ published theoretical models for electrochemical characterization and interpretation. Several reviews of modified electrodes have appeared ${ }^{7}$. Surface-modified electrodes can be subdivided according to the function of the immobilized species (IS) or the immobilization procedure used. The manner of functioning of the IS is often complex, nevertheless a division can be made into two main groups: electro-active and electro-inactive IS. Electro-active IS usually function as fast electron-transfer mediators and the electrochemical response should be reversible to preclude additional complications. Immobilized catalysts, one of the major manifestations of modified electrodes, are often electro-active (for instance: porphyrins). This also makes them suitable as electron mediators. The catalyst is electrochemically regenerated:

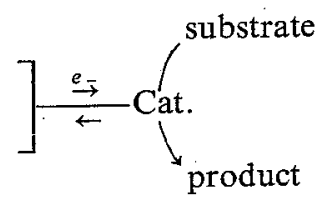

The immobilized (adsorbed, covalently bonded, etc.) molecules can perform reactions parallel to or in tandem with charge transfer. They can also function as an intermediate in redox catalysis or provide a stereo-selective environment for the electrode reaction.

Electro-inactive IS may function as anchors (silane reagent) for subsequent immobilization. They may also build up a suitable interface for solution species to interact with the electrode surface (e.g. cytochrome-c at a 4,4'-bipyridine-modified gold electrode). Finally, they may catalyse the electrode reaction without being reduced or oxidized themselves. In addition to the electro-activity, the optical activity of IS (such as that found in polyviologens, rhodamine-B and several other dyes) is exploited.

The most appropriate manner of immobilising the catalyst molecules is covalent bonding. This approach requires knowledge of the different types of groups present at the bare or pretreated electrode surface. Carbon, for example, possesses several surface groups, i.e. carboxyl, hydroxyl, quinone, etc., whose relative and absolute concentrations can be changed by certain oxidation techniques such as oxygen rf-plasma treatment. A very sensitive and promising technique for the characterization of electro-active surface groups or of immobilized species is phase-selective ac-voltammetry.

One of the main purposes of surface modification is the introduction of specific catalytic centres at an electron-conducting material. This can be illustrated by the following example. The cathodic reduction of oxygen to water is a very important reaction in energy conversion systems (fuel cell, metal-air battery). Usually, the expensive platinum is used as the active electrode material, although it is clearly of economic interest to look for cheaper electrode materials, such as carbon, modified with a catalyst, e.g. certain metal porphyrins. At a bare carbon electrode, oxygen is only reduced to hydrogen peroxide, whereas immobilized metal porphyrins can catalyze this reduction directly to water. Not only in electrocatalysis, but also in electroanalysis has the surface-modified electrode found application, i.e. as a sensor for the detection of metal ions, even at pico-molar concentration levels. A very interesting and promising field of application is that of bio(electro)chemistry. Modification of electrode surfaces with enzymes, where a direct electron transfer from electrode to enzyme is realized, [enzyme-modified electrode (EME)], has only recently been applied.

Enzymes are of special interest because of their high activity and specificity. A glucose-oxidase-modified electrode surface used as an in vivo glucose sensor, or a ferredoxin-NADP-reductase-modified electrode used for regenerating the co-enzyme NADPH, are two examples of the numerous applications possible in biochemistry.

\section{Modification procedures}

In general, the properties of the IS are known, but a suitable and reproducible immobilization procedure must be established. The preferred type of procedure depends upon the structure of the IS and/or upon the electrode surface [kind of functional group(s) present], as well as upon the function of the IS (electron mediator, anchor, catalyst, etc.). In principle, there are three main procedures used for the modification of electrode surfaces:

$\square$ covalent modification;

$\square$ adsorption modification;

$\square$ polymer-film modification.

The polymer-film modification may be considered as forming part of the first two procedures, although it is generally treated as a special class. It is a rapidly developing modification procedure with its own merits, and requires a special treatment from a theoretical point of view. A combination of these three main procedures is also possible, such as covalent modification of polymer films or adsorption modification at a covalently attached monolayer. Immobilization of enzymes onto electrode surfaces is a rather new topic in surface-modified electrodes and will be treated separately.

\section{Covalent modification}

The covalent-modification procedure implies a covalent bonding of the IS to the electrode surface. Three procedures will be distinguished, viz. covalent modification:

via a functional group at the electrode surface;

$\square$ via a bridge molecule (anchor);

via an activated surface.

(i) Covalent modification via a functional group at the electrode surface. Functional groups, already present at the surface or induced by special preparation techniques, are used for covalent bonding of the IS. Carbon surfaces are very suitable for this procedure, since a variety of

${ }^{52}$ A. P. Brown and F. C. Anson, Anal. Chem. 49, 1589 (1977).

${ }^{\mathrm{b}}$ C. A. Koval and F.C. Anson, ibidl 50, 223 (1978).

c A.P. Brown and F.C. Anson, J. Electroanal. Chem. 92, 133 (1978).

6a E. Laviron, Electroanal. Chemistry, Ed. A.J. Bard, vol. 12, p. $53-157$.

${ }^{2}$. Laviron, J. Electroanal. Chem. 52, 395 (1974).

${ }^{c}$ E. Laviron, ibid. 100, 263 (1979).

${ }^{\mathrm{d}}$ E. Laviron and L. Roullier, ibid. 115, 65 (1980).

' E. Laviron, ibid. 97, 135 (1979).

${ }^{\text {f }}$ E. Laviron, ibid. 105, 25 (1979).

${ }^{\prime} E$. Laviron, ibid. 105, 35 (1979).

${ }^{b}$ D. Lelievre, V. Plichon and E. Laviron, ibid. 112, 137 (1980).

${ }^{i}$ E. Laviron and L. Roullier, ibid. 115, 65 (1980).

${ }^{7 a}$ K. D. Snell and A. G. Keenan, Chem. Soc. Rev. 8, 259 (1979).

${ }^{b} R$. W. Murray, Acc. Chem. Res. 13, 135 (1980).

${ }^{\circ} M$. Noel, P. N. Anantharaman and H. V.K. Udupa, Trans. SAEST 15 (1), 49 (1980).

dE. Barendrecht and J.P.G.M. Schreurs, Chem. Mag. 145 (1981).

e R. W. Murray, Phil. Trans. R. Soc. Lond. A302, 253 (1981). 
surface groups are altready present (Fig. 1) ${ }^{8 a}$. It is possible to enhance the number or to create new surface functional groups, such as carboxyl, hydroxy, quinone, amino, nitro, bromo, etc., at the carbon surface via chemical $^{8 b, c}$, thermal ${ }^{8}$ or rf-plasma treatment ${ }^{4 a, b}$. Covalent bonds such as those found in amide, ester, ether, azo, etc., are now possible between the electrode surface and the IS. Covalent modification via the surface carboxylic group is shown in Fig. 2.
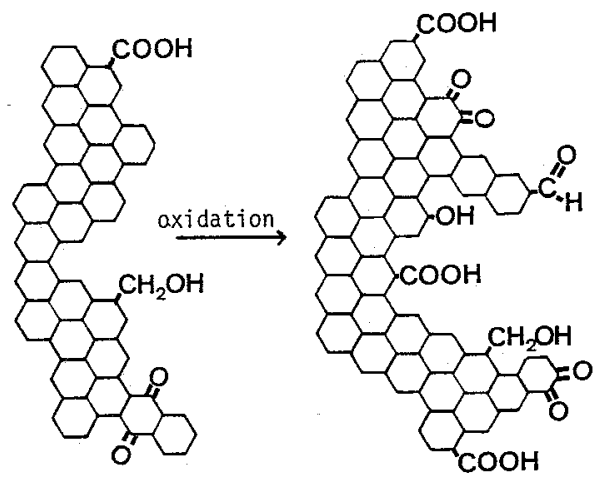

Fig. 1. Functional groups present at the edge plane of graphite or glassy carbon.

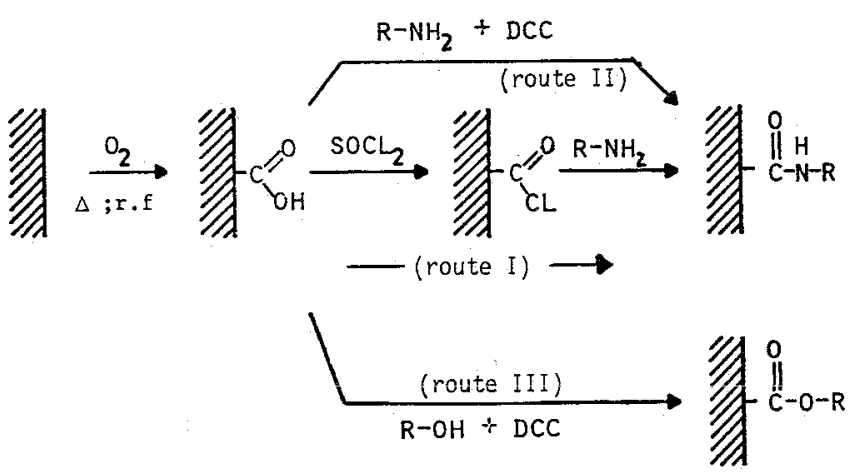

DCC = Dicyclohexylcarbodiimide

$\Delta=$ thermal if $=$ radio frequency plasma

Fig. 2. Covalent modification via the carboxylic surface group on glassy carbon.

Routes I and II show the possibility of immobilizing a species with an amine functional group, such as tetrakis ( $p$ -aminophenyl)porphyrins, at a glassy carbon electrode surface. Conversion of the carboxylic group into a carbochloride (route I) can be avoided by the use of a coupling reagent such as dicyclohexylcarbodiimide (DCC) (route II). Note that alkylamines react spontaneously ${ }^{10}$ with carboxylic surface groups, in contrast to arylamines.

For covalent modification, carbon electrodes such as glassy carbon ${ }^{11}$ or pyrolytic graphite ${ }^{12}$ are frequently used, as are metals such as $\mathrm{Pt}^{13}$ and $\mathrm{Au}^{14}$, metal oxides such as $\mathrm{SnO}_{2}{ }^{15}, \mathrm{TiO}_{2}{ }^{16}$ and $\mathrm{RuO}_{2}{ }^{17}$, and semi-conductors such as $\mathrm{Si}^{18}$ and $\mathrm{Ge}^{19}$. Covalent modification of the metals is accomplished via the surface-oxide groups created by oxidation techniques, while bulk oxides such as $\mathrm{TiO}_{2}$, $\mathrm{SnO}_{2}$, etc., already possess surface groups of their own. Carbon electrodes are usually modified via carboxylic and/or hydroxylic surface groups, but also via surface groups such as amine, bromide, etc., which can be generated via rf-plasma pretreatment ${ }^{46}$. Metal oxides are usually modified via ester or ether bonding with the surface hydroxyl group. $\mathrm{Osa}^{15 \mathrm{c}}$ modified $\mathrm{SnO}_{2}$ and $\mathrm{TiO}_{2}$ electrodes using dyes such as Rhodamine-B as a sensitizer, which shifted the optical sensitivity from the UV towards the visible region.
Ferrocene, covalently bonded to $n$-type semi-conducting $\mathrm{Ge}$ photoelectrodes, functions as an electron transfer mediator as well as a passivator with respect to semi-conductor decomposition in aqueous media ${ }^{19 a}$.

(ii) Covalent modification via a bridge molecule. Bridge molecules are very suitable for introducing a desired functional group at the electrode surface. The bridge molecule possesses at least two functional groups; one for covalent bonding to the electrode surface and one for covalent bonding of, for instance, a catalyst.

${ }^{8 a} J$. Schreurs, Thesis, Eindhoven University of Technology, 1983.

${ }^{b}$ M. Fujihira, A. Tamura and T. Osa, Rev. Polarogr. (Kyoto) 22, 87 (1976).

"M. Fujihira and T. Osa, "Progress in Batteries \& Solar Cells", ed. A. Kozawa et al., Vol. 2, IEC Press Inc. 1979, Cleveland.

9a J. C. Sheehan and G. P. Hess, J. Am. Chem. Soc. 77, 1967 (1955).

${ }^{b}$ F. Kurzer and K. Douraghi-Zadeh, Chem. Rev. 67(2), 107 (1967).

10 N. Oyama, K. B. Yap and F. C. Anson, J. Electroanal. Chem. 100, 233 (1979).

${ }^{11 a}$ See also refs. $3 b, f, i, o$

${ }^{b}$ C. M. Elliott and R. W. Murray, Anal. Chem. 48, 1247 (1976)

"N. Kobayashi, M. Fujihira and T. Osa, Chem. Lett. 575 (1982).

d $M$. Fujihira, A. Tamura and T. Osa, Chem. Lett. 361 (1977).

' N. Oyama and F.C. Anson, J. Am. Chem. Soc. 101, 1634 (1979).

' C.P. Jester, R. D. Rocklin and R. W. Murray, J. Electrochem. Soc. 127, 1979 (1980).

${ }^{g} O$. Haas and H. R. Zumbrunnen, Helv. Chim. Acta 64, 854 (1981).

${ }^{\text {h } C . M . ~ E l l i o t t ~ a n d ~ C . A . ~ M a u r e s e, ~ J . ~ E l e c t r o a n a l . ~ C h e m . ~} 119$, 395 (1981).

i R. D. Rocklin and R.W. Murray, J. Phys. Chem. 85, 2104 (1981).

${ }^{12 \mathrm{a}}$ See also refs. $1,2,3 \mathrm{a}$ and $11 \mathrm{e}, \mathrm{h}$.

${ }^{\mathrm{b}}$ J. F. Evans, T. Kuwana, M.T. Henne and G.P. Royer, J. Electroanal. Chem. 80, 409 (1977).

${ }^{c} M$. Fujihira, S. Tasaki, T. Osa and T. Kuwana, ibid. 137, 163 (1982).

${ }^{13 a}$ See also refs. $3 \mathrm{~g}, 1, \mathrm{n}$ and 111

${ }^{\mathrm{b}} H$. D. Abruña, T.J. Meyer and R. W. Murray, Inorg. Chem. 18, 3233 (1979).

'A.B. Fischer, M.S. Wrighton, M. Umaña and R. W. Murray, J. Am. Chem. Soc. 101, 3442 (1979).

${ }^{d} K . N$. Kuo and R.W. Murray, J. Electrochem. Soc. 129, 756 (1982).

'A. B. Fischer, J. A. Bruce, D. R. McKay, G. E. Macid and M.S. Wrighton, Inorg. Chem. 21, 1766 (1982).

${ }^{\circ}$ G. S. Calabrese, R. M. Buchanan and M.S. Wrighton, J. Am. Chem. Soc. 104, 5786 (1982).

14 See also ref. $13 \mathrm{c}$,e.

${ }^{15 a}$ See also ref. $20 \mathrm{i}$.

'T. Osa and M. Fujihira, Nature 264, 349 (1976).

' N. R. Armstrong, A. W. Lin, M. Fujihira and T. Kuwana, Anal. Chem. 48, 741 (1976).

${ }^{d} M$. Fujihira, N. Ohishi and T. Osa, Nature 268, 226 (1977).

e $M$. Fujihira, T. Osam, D. Hursh and T. Kuwana, J. Electroanal. Chem. 88, 285 (1978).

f D. D. Hawn and N.R. Armstrong, J. Phys. Chem. 82, 1288 (1978).

16 See ref. $15 b, d$.

${ }^{17 \mathrm{a}}$ See also ref. $13 \mathrm{~d}$.

${ }^{b} D$. R. Rolison, K. Kuo, M. Amaña, D. Brundage and R. W. Murray, J. Electrochem. Soc. 126, 407 (1979).

${ }^{18 a}$ See also ref. $13 \mathrm{e}$.

${ }^{\mathrm{b}}$ M.S. Wrighton, R. G. Austin, A.B. Bocarsly, J.M. Bolts, O. Haas, K. D. Legg, L. Nadjo and M. C. Palazzotto, J. Am. Chem. Soc. 100, 1602 (1978).

${ }^{c} H$. Yoneyama, Y. Murao and H. Tamura, J. Electroanal. Chem. 108, 87 (1980).

${ }^{19 a}$ See also refs. $13 \mathrm{e}$.

' J. M. Bolts and M. S. Wrighton, J. Am. Chem. Soc. 100, 5257 (1978). 
Some examples of functional groups comprising the bridge molecule (for subsequent modification) are amine, carboxyl, cyanide, sulfide and pyridine. Pyridine groups are very suitable for the complexation of metal ions. Murray ${ }^{20 a-g}$ introduced the silane reagents, such as (aminopropyl)triethoxysilane, which are now commonly

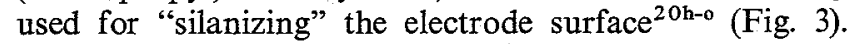

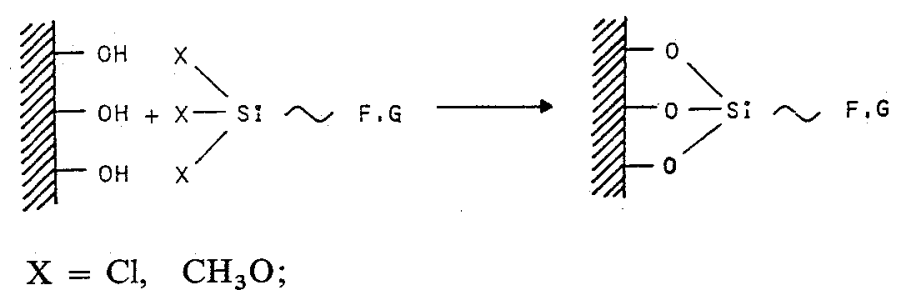

$$
\mathrm{FG}=\text { Functional Group }\left(-\mathrm{NH}_{2},-\mathrm{COOH}, \text { etc. }\right)
$$

Fig. 3. Silanization of a metal-oxide electrode surface.

However, by using a silane reagent, one creates an isolating chain between the electrode surface and the IS. This implies that charge transfer must proceed over large distances. Consequently, other mechanisms, such as hopping or tunnelling, might be involved. Kuwana ${ }^{21}$ introduced cyanuric chloride as a bridge molecule. This, however, possesses only one kind of functional group (chloride) for subsequent immobilization. In particular, metal-oxide electrodes, such as $\mathrm{SnO}_{2}, \mathrm{TiO}_{2}$ and $\mathrm{RuO}_{2}$, have been covalently modified via a bridge molecule. A variety of IS, such as ferrocene ${ }^{31}$, metal complexes ${ }^{13 b}$ and even polymers [poly(methacryl chloride) $\left.{ }^{22}\right]$, were thus immobilized.

(iii) Covalent módification via an activated surface. Activated electrode surfaces (mostly carbon or platinum) are created by removing surface groups and/or disrupting the surface structures, thus exposing the bulk structure having very reactive sites to the surface. This can be accomplished via vacuum pyrolysis ${ }^{23}$, mechanical abrasion in an inert atmosphere ${ }^{24}$ or by Ar rf-plasma pretreatment ${ }^{25}$. The activated surfaces are reactive towards vinyland amine-functional groups (Fig. 4), but probably equally well towards many other functional groups, molecules and even atoms. Vinyl- and aminoferrocene were thus immobilized by Murray ${ }^{3 \mathrm{~m}}$. A bridge molecule such as vinylpyridine was also immobilized in this way, and subsequently used for coordinating ruthenium complexes $^{26}$.

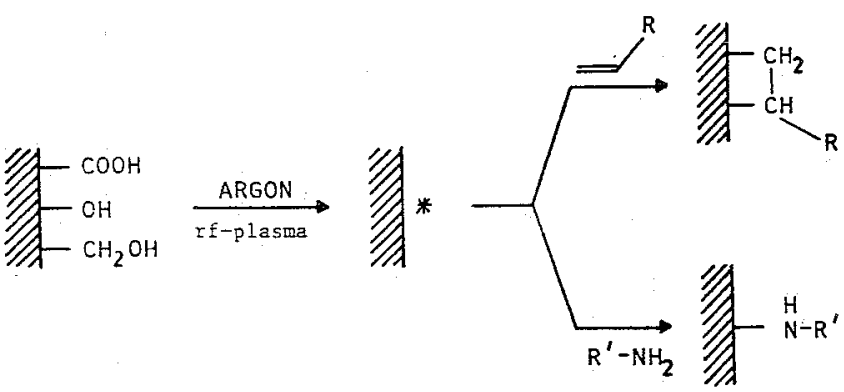

Fig. 4. Covalent modification via an activated carbon surface.

\section{Adsorption modification}

Despite the fact that adsorption modification produces less stable systems than covalent modification, this procedure is often applied because of its simplicity. Several such techniques, for example sublimation, adsorption from dilute solutions or electrosorption, are frequently used. A clear distinction between adsorption modification and covalent modification is not always possible. Ordinary adsorption, accomplished via van der Waals or coulombic interactions with the surface, is well defined, as is covalent bonding. However, for adsorption of halogens or ethylene compounds ${ }^{27}$ at a platinum surface, the type of bonding is less defined (chemisorption). As an example, Lane and Hubbard ${ }^{28}$ adsorbed functionalized olefins at platinum electrodes (Fig. 5a) and Edström ${ }^{29}$ used adsorbed allylamine as a bridge molecule for subsequent covalent bonding of ferrocenecarbaldehyde. Although a multilayer of $40-3000 \AA$ thickness ${ }^{30}$ is no longer the result of simple adsorption, this type will also be included in this section. Numerous systems have been immobilized via adsorption modification. We mention here adsorption of

${ }^{20 a}$ See also refs. 1 and $3 \mathrm{c}-\mathrm{f}, \mathrm{g}, \mathrm{j}, \mathrm{k}$.

b P. R. Moses, L. M. Wier, J.C. Lennox, H O. Finklea, J.R. Lenhard and R. W. Murray, Anal. Chem. 50, 576 (1978).

${ }^{c}$ K. W. Kuo, P. R. Moses, J. R. Lenhard, D. C. Green and R. W. Murray, ibid. 51, 745 (1979).

${ }^{d} H$. S. White and R. W. Murray, ibid. 51, 236 (1979).

' J. Facci and R.W. Murray, J. Electroanal. Chem. 112, 221 (1980).

${ }^{f}$ K. W. Willman, R.D. Rocklin, R. Nowak, K.W. Kuo, F.A. Schultz and R.W. Murray, J. Am. Chem. Soc. 102, 7629 (1980).

${ }^{g}$ H. O. Finklea, H. Abruña and R. W. Murray, Adv. Chem. Ser. 184, 253 (1980).

' M. Fujihira, T. Matsue and T. Osa, Chem. Lett. 875 (1976).

${ }^{\mathrm{i}} M$. A. Fox, F.J. Nobs and T. A. Voynich, J. Am. Chem. Soc. 102, 4029 (1980).

${ }^{\mathrm{j}}$ N.R. Armstrong and V.R. Shepard, jr., J. Electroanal. Chem. 115, 253 (1980).

${ }^{\mathrm{k}} M$. Fujihira, T. Kubota and T. Osa, ibid. 119, 379 (1981).

${ }^{1} M$. Sharp and M. Petersson, ibid. 122, 409 (1981).

${ }^{\mathrm{m}}$ H. D. Abruña, J. L. Walsh, T.J. Meyer and R.W. Murray, Inorg. Chem. 20, 1481 (1981).

"A.F. Diaz, F.A. Orozco Rosales, J. Paredon-Rosales and K. K. Kanazawa, J. Electroanal. Chem. 103, 233 (1979).

${ }^{\circ}$ R. C. Cieslinski and N. R. Armstrong, J. Electrochem. Soc. 127, 2605 (1980).

${ }^{21 \mathrm{a}}$ R.J.H. Wilson and M.D. Lilly, Biotechn. Bioeng. 11, 349 (1969).

' A.W.C. Lin, P. Yeh, A. M. Yacynych and T. Kuwana, J. Electroanal. Chem. 84, 411 (1977).

'D.C.S. Tse, G.P. Royer and T. Kuwana, ibid. 98, 345 (1979).

dM.F. Dantartas, J. F. Evans and T. Kuwana, Anal. Chem. 51, 104 (1979).

e A. M. Yacynych and T. Kuwana, ibid. 50, 640 (1978).

${ }_{22} K$. Itaya and A.J. Bard, Anal. Chem. 50, 1487 (1978).

23 S. Mazur, T. Matusinovic and $\dot{K}$. Cammann, J. Am. Chem. Soc. 99, 3888 (1977).

24 R. Nowak, F. A. Schultz, M. Umaña, H. Abruña and R. W. Murray, J. Electroanal. Chem. 94, 219 (1978).

${ }^{25 a}$ N. Oyama, A. P. Brown and F. C. Anson, J. Electroanal. Chem. 87, 435 (1978).

${ }^{\mathrm{b}}$ N. Oyama, A.P. Brown and F.C. Anson, ibid. 88, 289 (1978).

26 Symposium on Chemically Modified Electrodes, Electro- chemical Society Meeting, Boston MA, May 1979.

$H$. Abruña, K. Kuo, D. Rolison, M. Umaña and R. W. Murray, Abstract 293.

${ }^{27 a}$ R. F. Lane and A. T. Hubbard, J. Phys. Chem. 79, 808 (1975).

${ }^{b}$ R. F. Lane and A. T. Hubbard, ibid. 81, 734 (1977).

${ }^{28 \mathrm{a}}$ R. F. Lane and A. T. Hubbard, J. Phys. Chem. 77, 1401 (1973).

${ }^{\mathrm{b}}$ R. F. Lane and A. T. Hubbard, ibid. 77, 1411 (1973).

$29 M$. Sharp, M. Petersson and K. Edström, J. Electroanal. Chem. 95, 123 (1979).

3o F. R. Fan and L. R. Faulkner, J. Am. Chem. Soc 101- 4779 (1979). 
phthalocyanines and porphyrins onto carbon electrodes ${ }^{31}$, while adsorption of a bridge molecule such as pyridinesubstituted phenanthrene made it possible to immobilize ruthenium complexes ${ }^{32}$ (Fig. 5b). In addition to carbon, metals, metal oxides and even polymer compounds such as $(\mathrm{SN})_{x}{ }^{33}$, have been used for adsorption modification. The $(\mathrm{SN})_{x}$ electrode possesses a structure comparable to graphite, i.e. parallel planes (conjugated $\pi$-system) and perpendicular (edge) planes. Adsorption modification often results in a multilayer, while covalent modification only creates a monolayer.

\section{Polymer-film modification}

Recently, increasing attention has been paid to polymerfilm modification of electrode surfaces. The polymer film can be immobilized by covalent bonding or by adsorption, and also by mechanical anchoring (rough electrode surface). Polymer-film modification is treated separately, since an entirely new type of electrodes (multilayer) is created; this requires a special theoretical ${ }^{34}$ and preparative approach.

The polymer film is formed at the electrode surface by covalent bonding ${ }^{22}$, adsorption (dip-coating ${ }^{35}$, spin-coating $^{36}$ ), electrochemical polymerization ${ }^{37}$ and/or deposition $^{38}$, and rf-plasma polymerization ${ }^{39}$. With the exception of polyacrylonitrile (black orlon) ${ }^{39 a}$ and poly-

${ }^{31 a}$ A. P. Brown, C. Koval and F. C. Anson, J. Electroanal. Chem. 72, 379 (1976).

' J. Zagal, R. K. Sen and E. Yeager, ibid. 83, 207 (1977).

' J. P. Collman, M. Marrocco, P. Denisevich, C. Koval and F. C. Anson, ibid. 101, 117 (1979).

d V.R. Shepard and N.R. Armstrong, J. Phys. Chem. 83, 1268 (1979).

e $J$. H. Zagal, J. Electroanal. Chem. 109, 389 (1980).

f $J$. Zagal, C. Fierro and R. Rozas, ibid. 119, 403 (1980).

${ }^{g}$ T. Kikuchi, H. Sasaki and S. Toshima, Chem. Lett. 5 (1980).

${ }^{\mathrm{h}}$ W. J. Blaedel and G. A. Mabbott, Anal. Chem. 53, 2270 (1981).

${ }^{i}$ J. H. Zagal, Contrib. Cient. Tecnol. 11, 49. (1981).

${ }^{j} R$. R. Durand, Jr. and F. C. Anson, J. Electroanal. Chem. 134, 273 (1982).

${ }^{\mathrm{k}}$ J. Zagal, E. Villar and S. Ureta-Zanartu, ibid. 135, 343 (1982).

${ }^{1}$ K. Shigehara and F. C. Anson, J. Phys. Chem. 86, 2776 (1982).

${ }^{\mathrm{m}} J$. Zagal and S. Ureta-Zanartu, J. Electrochem. Soc. 129, 2242 (1982).

"A. Bettelheim, R. Parash and D. Ozek, J. Electrochem. Soc. 129, 2247 (1982).

32 A. P. Brown and F. C. Anson, J. Electroanal. Chem. 83, 203 (1977).

33 R.J. Nowak, W. Kutner, H. B. Mark and A. G. MacDiarmid, J. Electrochem. Soc. 125, 232 (1978).

${ }^{34 a} M$. Delamar, M.C. Pham, P.C. Lacaze and J.E. Dubois, J. Electroanal. Chem. 108, 1 (1980).

${ }^{b} K$. Doblhofer, Electrochim. Acta 25, 871 (1980).

${ }^{c} E$. Laviron, J. Electroanal. Chem. 112, 1 (1980).

${ }^{\mathrm{d}}$ E. Laviron, L. Roullier and C. Degrand, ibid. 112, 11 (1980).

' P.J. Peerce and A.J. Bard, ibid. 112, 97 (1980).

' P.J. Peerce and A.J. Bard, ibid. 114, 89 (1980).

${ }^{g}$ P. C. Lacaze, M. C. Pham, M. Delamar and J.E. Dubois, ibid. 108, 1 (1980).

${ }^{n} J$. Facci and R. W. Murray, ibid. 124, 339 (1981).

i D. A. Buttry and F. C. Anson, ibid. 130, 333 (1980).

${ }^{j}$ E. Laviron, ibid. 131, 61 (1982).

${ }^{\mathbf{k}} M$. Lovric, Electrochim. Acta 26, 1639 (1982).

${ }^{1}$ C. P. Andrieux and J.M. Saveant, J. Electroanal. Chem. 134, 163 (1982).

${ }^{\mathrm{m}}$ C. P. Andrieux, J. M. Dumas-Bonchiat and J. M. Saveant, ibid. 131, 1 (1982).

${ }^{n}$ S. N. Bhadani, R.S. Prasad and G. Parravano, Polym. J. (Tokyo) 14, 1 (1982).

- R.J. Mortimer and F.C. Anson, J. Electroanal. Chem. 138, 325 (1982).

${ }^{\mathbf{p}}$ T. Ikada, C. K. Leidner and R.W. Murray, ibid. 138, 343 (1982).

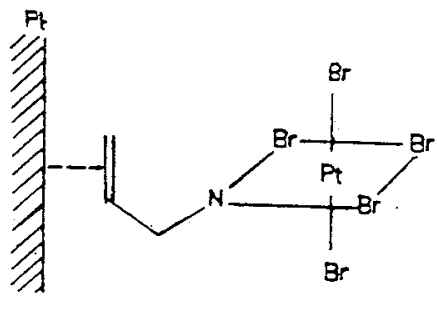

(a)

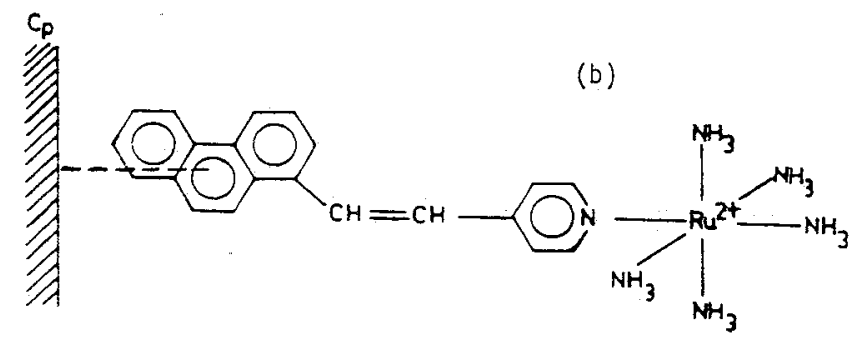

Fig. 5. Adsorption modification:

a) chemisorption of a functionalized vinyl compound at a platinum electrode ${ }^{28}$;

b) ruthenium complexes immobilized via an adsorbed bridge molecule, at a pyrolytic graphite $\left(\mathrm{C}_{\mathrm{p}}\right)$ electrode ${ }^{32}$.

${ }^{35 a}$ L. L. Miller and M.R. van de Mark, J. Am. Chem. Soc. 100, 639 (1978).

b M. R. van de Mark and L. L. Miller, ibid. 100, 3223 (1978).

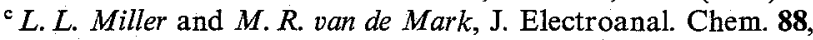
437 (1978).

d J. B. Kerr, L. L. Miller and M. R. van de Mark, J. Am. Chem. Soc. 102, 3383 (1980).

' C. Degrand and L. L. Miller, J. Electroanal. Chem. 117, 267 (1981).

${ }^{36 a}$ H. Tachikawa and L. R. Faulkner, J. Am. Chem. Soc. 100, 4379 (1978).

${ }^{\mathrm{b}}$ H. Tachikawa and L. R. Faulkner, ibid. 100, 8025 (1978).

' $F$. B. Kaufman and E. M. Engler, ibid. 101, 547 (1979).

d F. B. Kaufman, A.M. Schroeder, E. M. Engler, S. R. Kramer and J.Q. Chambers, ibid. 102, 483 (1980).

${ }^{37 a}$ L. A. Korshikov, A.P. Karpinets and V.D. Bezuglyi, Sov. Electrochem. 10, 946 (1974).

${ }^{b}$ M.C. Pham, P.C. Lacaze and J.E. Dubois, J. Electroanal. Chem. 86, 147 (1978).

'M.C. Pham, P.C. Lacaze and J.E. Dubois, ibid. 99, 331 (1979).

dA. Volkov, G. Tourillon, P.C. Lacaze and J.E. Dubois, J. Electroanal. Chem. 115, 279 (1980).

${ }^{'} H . D$. Abruña, P. Denisevich, M. Umaña, T.J. Meyer and R. W. Murray, J. Am. Chem. Soc. 103, 1 (1981).

${ }^{f}$ P. K. Ghosh and T.G. Spiro, J. Electrochem. Soc. 128, 1281 (1981).

B. M. Tidswell and D. A. Mortimer, Eur. Polym. J. 17, 735 (1981).

${ }^{\text {h }}$ B. M. Tidswell and D. A. Mortimer, ibid. 17, 745 (1981).

${ }^{i}$ C. D. Ellis, W. R. Murphy, Jr. and T.J. Meyer, J. Am. Chem. Soc. 103, 7480 (1981).

i M. C. Phan, J.E. Dubois and P.C. Lacaze, J. Electrochem. Soc. 130, 346 (1983).

${ }^{\mathrm{k}}$ G. Cheek, C. P. Wales and R.J. Nowak, Anal. Chem. 55, 380 (1983).

38 R. V. Subramanian, Púre Appl. Chem. 52, 1929 (1980).

${ }^{39 a} K$. Doblhofer, O. Nölte and J. Ulstrup, Ber. Bunsenges. Phys. Chem. 82, 403 (1978).

${ }^{\mathrm{b}} K$. Doblhofer and W. Dürr, J. Electrochem. Soc. 127, 1041 (1980).

' M.F. Dantartas and J.F. Evans, J. Electroanal. Chem. 109, 301 (1980).

d M.F. Dantartas, K. R. Mann and J.F. Evans, ibid. 110, 379 (1980).

' P. Daum and R. W. Murray, J. Phys. Chem. 85, 389 (1981).

' G. H. Heider, Jr., M. B. Gelbert and A.M. Yacynych, Anal. Chem. 54, 322 (1982) 
meric sulfur nitride $(\mathrm{SN})_{x}{ }^{49}$, polymers such as polyacetylene ${ }^{41}$, poly $(p \text {-phenylene })^{42}$, etc., are rather poor conductors $\left(\kappa \approx 10^{-4} \Omega^{-1} \cdot \mathrm{cm}^{-1}\right)$. The specific conductivity $(\kappa)$ can be improved by controlled doping with alkali metals or halogens, which leads to $n$ - or $p$-type semi-conductors. Diaz ${ }^{43}$ introduced the surface synthesis of polypyrrole, which belongs to a new class of electrochemically synthesized conducting polymers (e.g. polyaniline, polyfuran, polyindole and polyazulene ${ }^{44}$ ) having conductivities of up to $10^{+2} \Omega^{-1} \cdot \mathrm{cm}^{-1}$. Polymers such as poly(4-vinylpyridine) ${ }^{45}$ already possess a functional group, so that metal complexes such as Ru(III)-EDTA can be immobilized (Fig. 6). Covalent bonding ${ }^{46}$ and entrapment ${ }^{47}$ of electro-active species are also possible. Electroactive species such as vinylferrocene ${ }^{48}$, viologen ${ }^{49}$ and even phthalocyanine ${ }^{50}$ can be polymerized to obtain an electro-, photo- or catalytically-active polymer film. An extensive study has been made by Bard et al. ${ }^{51}$. Not only have the physical (conductivity) and chemical properties (functional group) been studied but also the morphology of the polymer film ${ }^{52}$.

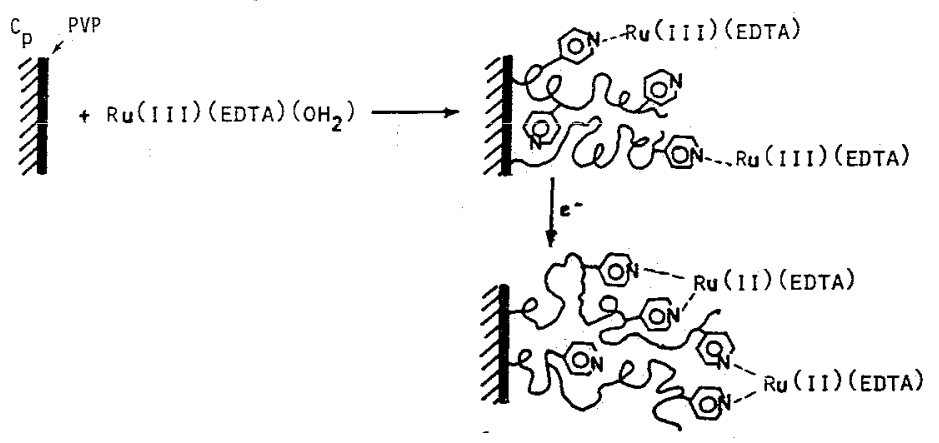

Fig. 6. Polymer-film-modified electrode. Immobilized ruthenium complexes at pyrolytic-graphite $\left(\mathrm{C}_{\mathrm{p}}\right)$ electrode modified with PVP, i.e. poly(4-vinylpyridine) ${ }^{45}$.

Polymer films have several advantages over covalently bonded or adsorbed monolayers. The polymer films are more rigid, possess a high active-centre site concentration and offer a wide area for exploitation. However, the electrochemistry of polymer-film electrodes is difficult to treat theoretically and problems of electron transfer and mass transport may also arise.

\section{Electrochemical characterization}

For the characterization of modified electrode surfaces, a variety of techniques is available. Identification of immobilized species is possible using FT-IR, ESCA, etc. However, only a few techniques are suitable for in situ measurements, which are important for kinetic studies of surface reactions. Resonance Raman Spectroscopy ${ }^{53}$ and Photoacoustic Spectroscopy ${ }^{54}$ are examples of methods already applied to in situ measurements.

Electrochemical techniques are particularly suited for in situ analyses of surfaces modified with electroactive species. By using optical transparent electrodes (OTE), it is possible to combine spectroscopic techniques such as UV/VIS with electrochemical methods ${ }^{55}$. Perturbation techniques such as impedance measurements, ac-voltammetry and differential pulse voltammetry are extremely sensitive towards changes at the electrode surface, with the result that even fractions of a monolayer can be detected. A very elegant and fast method is cyclic voltammetry (CV). Although less sensitive, $\mathrm{CV}$ is often used because of its power for qualitatively revealing mechanistic aspects of the electrode reaction and because of the rather simple experimental set-up. The theories for these electrochemical
${ }^{40 a}$ V. V. Walatka, M. M. Labes and J.H. Perlstein, Phys. Rev. Lett. 31, 1139 (1973).

${ }^{\mathrm{b}}$ J. F. Rubinson, T.D. Behymer and H. B. Mark, Jr., J. Am. Chem. Soc. 104, 1224 (1982).

41 A. G. MacDiarmid and A. J. Heeger, Synth. Met. 1, 101 (1980).

42 D. M. Ivory, G. G. Miller, J. M. Sowa, L. W. Shacklette, R. R. Chance and R. H. Baughman, J. Phys. Chem. 71, 1506 (1979).

${ }^{43 a}$ A. F. Diaz and K. K. Kanazawa, J. Chem. Soc. Chem. Commun. 635,854 (1979).

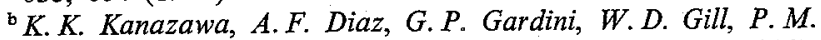
Grant, J. F. Kuak and G. B. Street, Synt. Meth. 1, 329 (1980).

'A.F. Diaz, W. Y. Lee, A. Logan and D. G. Green, J. Electroanal. Chem. 108, 377 (1980).

${ }^{d}$ A.F. Diaz and J. A. Logan, ibid. 111, 111 (1980).

'A.F. Diaz, J. I. Castillo, J. A. Logan and W. Y. Lee, ibid. 129, $115(1981)$

${ }^{\mathrm{f}}$ A.F. Diaz, J.M. Vasquez-Vallego and A. Martinez Duran, IBM J. Res. Develop. 25, 42 (1981).

A.F. Diaz, K. K. Kanazawa, J. I. Castillo and J.A. Logan, Polym. Sci. Technol. 15, 149 (1981).

${ }^{44 a} G$. Tourillon and F. Garnier, J. Electroanal. Chem. 135, 173 (1982).

' R. Noufi, A.J. Nozik, J. White and L.F. Warren, J. Electrochem. Soc. 129, 2261 (1982).

${ }^{45 a}$ N. Oyama and F.C. Anson, J. Am. Chem. Soc. 101, 3450 (1979).

b N.S. Scott, N. Oyama and F.C. Anson, J. Electroanal. Chem. 110, 303 (1980).

- T. Shimomura, N. Oyama and F. C. Anson, ibid. 112, 265 (1980).

d $O$. Haas and J. G. Vos, ibid. 113, 139 (1980).

' $N$. Oyama and F.C. Anson, J. Electrochem. Soc. 127, 640 (1980).

f $P$. Denisevich, H.D. Abruña, C.R. Leidner, T.J. Meyer and R. W. Murray, Inorg. Chem. 2153 (1982).

${ }^{46 a}$ A. Bettelheim, R.J.H. Chan and T. Kuwana, J. Electroanal. Chem. 110, 93 (1980).

${ }^{b} K$. Shigehara and F. C. Anson, J. Electroanal. Chem. 132, 107 (1982).

47 K. N. Kuo and R.W. Murray, J. Electroanal. Chem. 131, 37 (1982).

${ }^{48 a}$ A. Merz and A. J. Bard, J. Am. Chem. Soc. 100, 3222 (1978).

b P.J. Peerce and A.J. Bard, J. Electroanal. Chem. 112, 97 (1980).

${ }^{49 a}$ H. D. Abruña and A.J. Bard, J. Am. Chem. Soc. 113, 6898 (1981).

b $K . W$. Willman and $R . W$. Murray, J. Electroanal. Chem. 133, 24 (1982).

${ }^{c}$ C. M. Elliott and W.S. Martin, ibid. 137, 377 (1982).

d $P$. Martigny and F. C. Anson, ibid. 139, 383 (1982).

soa P. M. Kusnesof, K. Wynne, R. S. Nohr and M. Kenney, J. Chem. Soc. Chem. Commun. 121 (1980).

${ }^{\mathrm{b}}$ K. F. Schoch, B. R. Kundulkar and T.J. Marks, J. Am. Chem. Soc. 101, 7071 (1980).

- L. Kreja and A. Plenka, Electrochim. Acta 27, 251 (1982).

s1a P.J. Peerce and A.J. Bard, J. Electroanal. Chem. 108, 121 (1980).

b P.J. Peerce and A.J. Bard, ibid. 112, 97 (1980).

c P.J. Peerce and A.J. Bard, ibid. 114, 89 (1980).

d I. Rubinstein and A.J. Bard, J. Am. Chem. Soc. 102, 6641 (1980).

e T.P. Henning, H.S. White and A.J. Bard, ibid. 103, 3937 (1981).

i $R . A$. Bull, F. R. F. Fan and A.J. Bard, J. Electrochem. Soc. 129, 1009 (1982).

${ }^{\text {g }}$ T. P. Henning, H. S. White and A. J. Bard, J. Am. Chem. Soc. 104, 5862 (1982).

${ }^{52 a}$ A. H. Schröder, F.B. Kaufman, V. Patel and E.M. Engler, J. Electroanal. Chem. 113, 193 (1980).

${ }^{\circ}$ Ibid. 113, 209 (1980).

${ }^{c} F$. B. Kaufman, A. H. Schroeder, E. M. Engler, S. R. Kramer and J. C. Chamber, J. Am. Chem. Soc. 102, 483 (1980).

${ }^{53 a} R$. Kötz and E. Yeager, J. Electroanal. Chem. 113, 113 (1980).

b W. L. Wallace, C. D. Jeager and A.J. Bard, J. Am. Chem. Soc. 101, 4880 (1979).

54 C. H. Lochmüller, S.F. Marshall and D.R. Wilder, Anal. Chem. 52, 19 (1980).

s5 T. Kuwana and $N$. Winograd, in "Electroanalytical-Chemistry", A.J. Bard, ed., Dekker, New York, vol. 7, p. 1. $\mathrm{t}$

is

a

c

C

$\mathrm{F}$

si

c

$\xi$

w

tl

C

e

I

V

$\mathrm{s}$

$i_{c}$

C

$i_{\varepsilon}$

ท

fo

$E$

e

In

$i_{\mathrm{s}}$

[uf 
techniques are in this case deduced from adsorption theories $^{6 a}$. In the following discussion only the characteristic elements of the theories of cyclic voltammetry and ac-voltammetry for a surface-immobilized redox system are presented.

Non-ideality, caused by interactions between the molecules, is also reviewed.

\section{Cyclic voltammetry ( $\mathrm{CV})$}

For an $n$-electron surface redox reaction involving reversible charge transfer and no interaction between the molecules, the Nernst equation can be written as:

$\xi=\frac{\Gamma_{\mathrm{o}}}{\Gamma_{\mathbf{R}}}=\exp \frac{n F}{R T}\left(E-E^{0^{\prime}}\right)$

where $\Gamma_{i}$ is the surface concentration of species $i$ and $E^{0^{\prime}}$ is the standard potential of the surface redox reaction. Both $O$ (Oxidator) and $R$ (Reductor) species are confined to the electrode surface, thus

$\Gamma_{\mathrm{o}}+\Gamma_{\mathbf{R}}=\Gamma_{\mathrm{T}}$

where $\Gamma_{T}$ is the total surface concentration of the redox species.

For the cathodic, respectively, anodic current we can write

$i_{\mathrm{c}}=-n F A \frac{\mathrm{d} \Gamma_{\mathrm{o}}}{\mathrm{d} t}$ and $i_{\mathrm{a}}=n F A \frac{\mathrm{d} \Gamma_{\mathbf{R}}}{\mathrm{d} t}$

Combining eqns. 1,2 and 3 , we have

$i_{\mathrm{a}}=\left|i_{\mathrm{c}}\right|=\frac{n^{2} F^{2} A \Gamma_{\mathrm{T}} v}{R T} \times \frac{\xi}{(1+\xi)^{2}}$

where $v=\frac{\mathrm{d} E}{\mathrm{~d} t}$ is the potential scan rate. This expression for the current represents a symmetrical curve around $E=E^{0^{\prime}}$, (Fig. 7). The peakwidth at mid-height $\left(W_{\frac{1}{2}}\right)$ is equal to $90.6 / \mathrm{n} \mathrm{mV}$ at $25^{\circ} \mathrm{C}$. Cathodic and anodic current are both at their peak value for $E=E^{0^{\prime}}$, and have equal magnitudes.

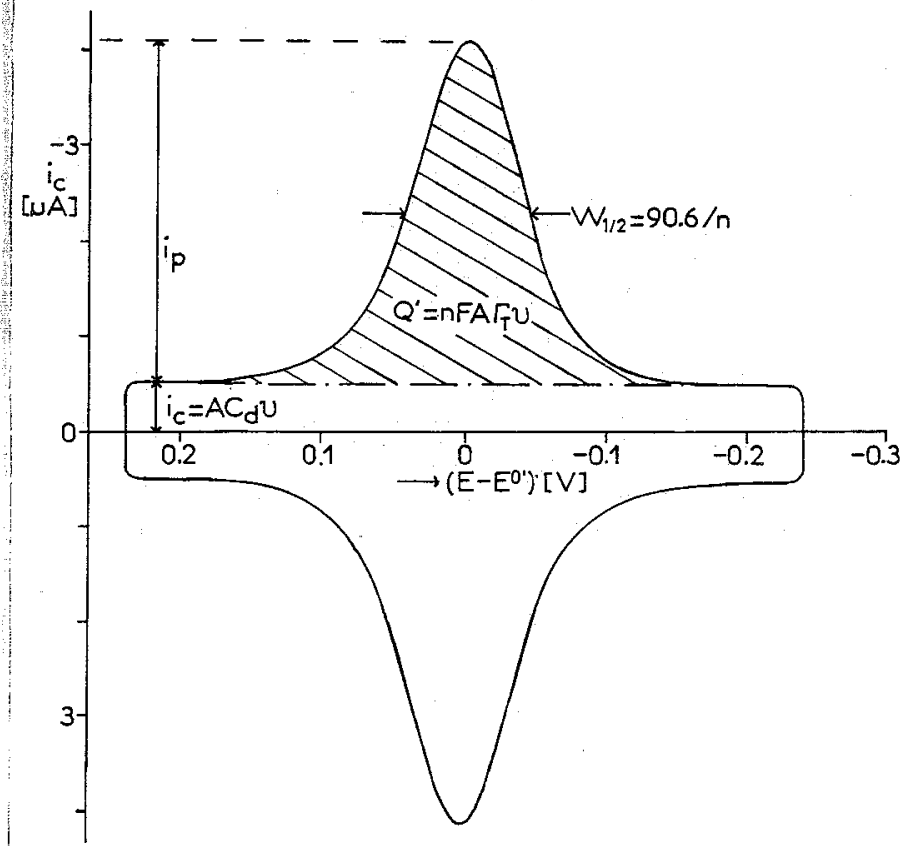

Fig. 7. Cyclic voltammogram for the reaox reaction $\mathrm{O}+n \mathrm{e}^{-} \rightleftarrows \mathrm{R}$ with both $\mathrm{O}$ and $\mathrm{R}$ attached to the electrode surface.

$\Gamma_{\mathrm{T}}=1.1 \cdot 10^{-10} \mathrm{~mol} \cdot \mathrm{cm}^{-2}, A=0.35 \mathrm{~cm}^{2}, n=1$ and $v=0.1 V \cdot s^{-1}$. $i_{\mathrm{p}_{\mathrm{a}}}=\left|i_{\mathrm{p}_{\mathrm{o}}}\right|=\frac{n^{2} F^{2} A \Gamma_{\mathrm{T}} v}{4 R T}$

To account for the non-ideal behaviour of the attached molecules ${ }^{57}$, surface activities rather than surface concentrations must be used. The Nernst equation now becomes

$\exp \frac{n F}{R T}\left(E-E^{0^{\prime}}\right)=\frac{a_{\mathrm{O}}}{a_{\mathrm{R}}}=\frac{\gamma_{\mathrm{O}} \Gamma_{\mathrm{O}}}{\gamma_{\mathrm{R}} \Gamma_{\mathrm{R}}}$

where $a_{i}$ and $\gamma_{i}$ are the surface activity and activity coefficients of species $i$, respectively. The activity coefficients are defined by ${ }^{5 a}$ ( $c f$. a Frumkin isotherm)

$\gamma_{\mathrm{O}}=\exp \left[-\left(r_{\mathrm{OO}} \Gamma_{\mathrm{O}}+r_{\mathrm{OR}} \Gamma_{\mathrm{R}}\right)\right]$

$\gamma_{R}=\exp \left[-\left(r_{R R} \Gamma_{R}+r_{R O} \Gamma_{O}\right)\right]$

where $r_{i i}$ and $r_{i j}$ are the non-ideality or interaction parameters describing the mutual interaction between species $i$ and $i$, and $i$ and $j$, respectively.

The current-potential behaviour for cyclic voltammetry is now described by

$i=\frac{n^{2} F^{2} A \Gamma_{\mathrm{T}} v}{R T} \times \frac{\xi^{*}}{\left(1+\xi^{*}\right)^{2}-2 r \Gamma_{\mathrm{T}} \xi^{*}}$

where

$\xi^{*}=\exp \frac{n F}{R T}\left(E-E^{0^{\prime}}\right)+2 r \Gamma_{0}-r_{\mathrm{R}} \Gamma_{\mathrm{T}}$

The individual parameters have been grouped as $r_{\mathrm{O}}=$ $r_{\mathrm{OO}}-r_{\mathrm{RO}}, r_{\mathrm{R}}=r_{\mathrm{RR}}-r_{\mathrm{OR}}$ and $r=0.5\left(r_{\mathrm{O}}+r_{\mathrm{R}}\right)$. For $r=0$, equation (9) reduces to equation (4). The cathodic and anodic currents are at their peak values at the same potential, i.e.

$E_{\mathrm{p}_{\mathrm{a}}}=E_{\mathrm{p}_{\mathrm{o}}}=E^{0^{\prime}}-\frac{R T}{2 n F}\left(r_{\mathrm{O}}-r_{\mathrm{R}}\right) \Gamma_{\mathrm{T}}$

with equal magnitudes:

$i_{\mathrm{p}_{\mathrm{a}}}=\left|i_{\mathrm{p}_{\mathrm{c}}}\right|=\frac{n^{2} F^{2} A \Gamma_{\mathrm{T}} v}{R T\left(4-2 r \Gamma_{\mathrm{T}}\right)}$

The peak potentials are equal but shift along the potential axis as a function of the total surface concentration $\left(\Gamma_{\mathrm{T}}\right)$ unless $r_{\mathrm{O}}=r_{\mathrm{R}}$. The width of the current peak at mid-height $\left(W_{\frac{1}{2}}\right)$ is

$W_{\frac{1}{2}}=\frac{2 R T}{n F}\left|\ln P-2 r \Gamma_{\mathrm{T}} \frac{P-1}{2 P+2}\right|$

where

$P=3-r \Gamma_{\mathrm{T}}+\left(r^{2} \Gamma_{\mathrm{T}}^{2}-6 r \Gamma_{\mathrm{T}}+8\right)^{\frac{1}{2}}$

For negative values of $r$, i.e. repulsive or destabilizing interactions, the current-potential peak is broadened, compared to the $90.6 / \mathrm{n} \mathrm{mV}$ for $r=0$. Stabilizing or attractive interactions (e.g. surface crystallization) are denoted by positive $r$ values and the peak in this case becomes narrowed.

56 A. T. Hubbard and F. C. Anson, Anal. Chem. 38, 58 (1966)

57 See refs. 3n, $5 a$ and $6 b$. 
Table I Surface concentration $\left(\Gamma_{\mathrm{T}}\right)$, the interaction parameter $(r)$ and the calculated, respectively, measured peak width at mid-height $\left(W_{1}\right)$, determined from the cyclic voltammograms of the $\mathrm{Cg}^{2}-\mathrm{Co} \mathrm{T}\left(\mathrm{pNH}_{2}\right) \mathrm{PP}$ electrode (Fig. 10b.)

\begin{tabular}{|c|c|c|c|c|c|}
\hline $\begin{array}{c}v \\
\left(\mathrm{~V} \cdot \mathrm{s}^{-1}\right)\end{array}$ & $\begin{array}{c}\Gamma_{\mathrm{T}} \times 10^{1 \mathrm{~T}} \\
\left(\mathrm{~mol} \cdot \mathrm{cm}^{-2}\right)\end{array}$ & $\begin{array}{c}r^{\mathrm{a}} \times 10^{-9} \\
\left(\mathrm{~cm} 2 \cdot \mathrm{mol}^{-1}\right)\end{array}$ & $\begin{array}{c}r \Gamma_{\mathrm{T}} \\
-\end{array}$ & $\begin{array}{c}W_{\frac{1}{2}}(\mathrm{calc})^{\mathrm{b}} \\
(\mathrm{mV})\end{array}$ & $\begin{array}{c}W_{\frac{1}{2}}(\mathrm{meas}) \\
(\mathrm{mV})\end{array}$ \\
\hline 0.2 & 1.76 & -5.5 & -0.97 & 141 & 134 \\
0.3 & 1.71 & -5.3 & -0.91 & 137 & 133 \\
0.4 & 1.72 & -5.7 & -0.98 & 141 & 133 \\
0.5 & 1.72 & -5.9 & -1.02 & 144 & 140 \\
\hline
\end{tabular}

${ }^{\mathrm{a}} \mathrm{r}=0.5\left(r_{\mathrm{O}}+r_{\mathrm{R}}\right) . \quad$ b Calculated using Eq. 16.

\section{ac-Voltammetry}

In ac-voltammetry, an alternating tension [of small amplitude $(\varepsilon)]$ is superimposed on the dc-potential scan. The current response is generally out of phase with the applied potential and is defined by

$i=I \sin (\omega t+\phi)$

where $\phi$ is the phase angle, $\omega$ the angular frequency and $I$ the amplitude of the alternating current.

Using a derivation analogous to that used for cyclic voltammetry, one obtains ${ }^{6 c}$ :

$i_{\mathrm{ac}}=\frac{n^{2} F^{2} A \Gamma_{\mathrm{T}} \varepsilon \omega}{R T} \frac{\xi}{(1+\xi)^{2}} \sin (\omega t+\pi / 2)$

This equation also represents a symmetrical curve around $E=E^{0^{\prime}}$ (Fig. 8) and the peak width at mid-height $\left(W_{\frac{1}{2}}\right)$ is again $90.6 / \mathrm{n} \mathrm{mV}$.

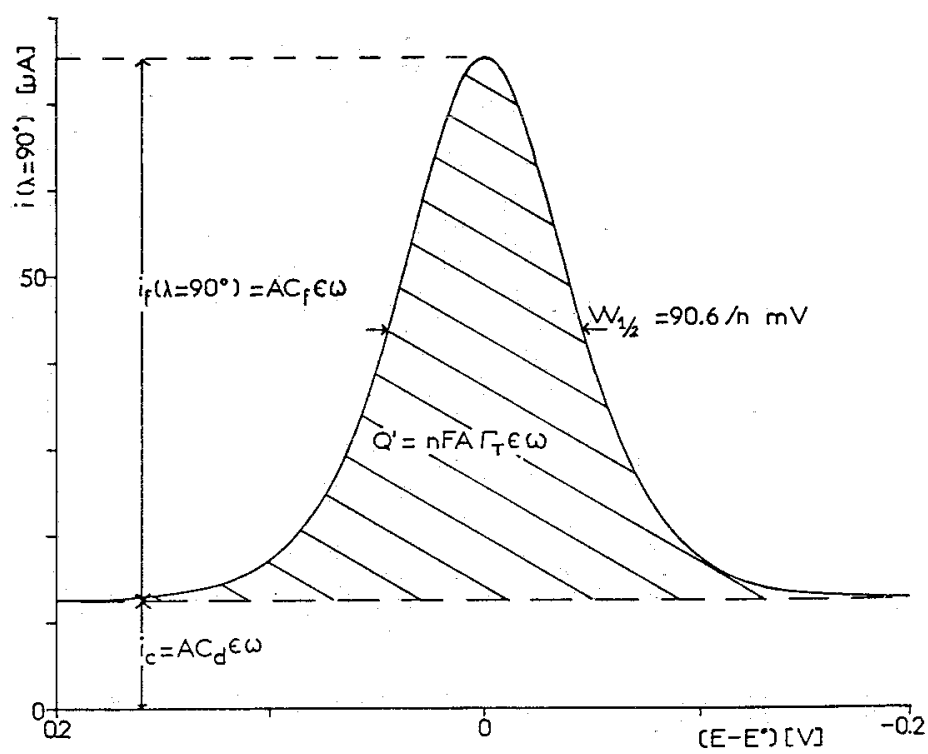

Fig. 8. ac-Voltammogram for the redox reaction $\mathrm{O}+n \mathrm{e}^{-} \rightleftarrows \mathrm{R}$, where both $\mathrm{O}$ and $\mathrm{R}$ are attached to the electrode surface.

$\lambda=90^{\circ}, \Gamma_{\mathrm{T}}=3.8 \cdot 10^{-11} \mathrm{~mol} \cdot \mathrm{cm}^{-2}, C_{\mathrm{d}}=10 \mu \mathrm{F}$, $\omega=2 \pi 20 \mathrm{~s}^{-1}, \varepsilon=0.01 \mathrm{~V}, n=1$ and $A=0.35 \mathrm{~cm}^{2}$.

As with equation (5), the peak current (maximal for $E=E^{0^{\prime}}$ ) is

$i_{\mathrm{p}}=\frac{n^{2} F^{2} A \Gamma_{\mathrm{T}} \varepsilon \omega}{4 R T} \sin (\omega t+\pi / 2)$

where the phase angle $\phi=\pi / 2$.

The equations which describe the current peak in the ac-voltammogram, taking into account the non-ideal behaviour (Frumkin isotherm) ${ }^{\mathrm{sf}}$, are analogous to those derived for the cyclic voltammogram, except that the potential scan rate $(v)$ is now replaced by $\varepsilon$ and $\omega$, while the phase angle remains $\pi / 2$. The peak current, for example, is now given by:

$i_{\mathrm{p}}=\frac{n^{2} F^{2} A \Gamma_{\mathrm{T}} \varepsilon \omega}{R T\left(4-2 r \Gamma_{\mathrm{T}}\right)} \sin (\omega t+\pi / 2)$

The effect of the interaction between the molecules on the shape of the current peak is also similar to that observed in cyclic voltammetry.

\section{Summary and illustrative example}

The cyclic voltammogram for a reversible surface redox reaction shows the following characteristics:

- symmetrical curve around $E=E^{0^{\prime}}$

$-\Delta E_{\mathrm{p}}=\left(E_{\mathrm{p}_{\mathrm{c}}}-E_{\mathrm{p}_{\mathrm{a}}}\right)=0 \quad\left(E_{\mathrm{p}}=E^{0 \prime}\right)$

$-i_{\mathrm{p}} \sim v$

This is in contrast to the electrode reaction of species in solution:

- no symmetrical curves

$-\Delta E_{\mathrm{p}}=59 / \mathrm{n} \mathrm{mV}$

$-i_{\mathrm{p}} \sim \sqrt{v}$

In particular, the difference in the dependence on the potential scan rate $(v)$ makes it possible to distinguish between a surface and a solution redox reaction.

In the ac-voltammogram of a surface redox reaction the following characteristics are observed

$-\phi=\pi / 2$ and

$-i_{\mathrm{p}} \sim \omega$

while for an electrode reaction of species in solution we have

$-\phi=45^{\circ}$ and

$-i_{\mathrm{p}} \sim \sqrt{\omega}$

Thus, phase-selective ac-voltammetry allows one to differentiate between a surface and a solution redox reaction, not only because of the difference in the dependence on $\omega$, but also because of the phase-angle difference.

The theory described above can be illustrated with some of our results obtained using cobalt(II) tetrakis(p-aminophenyl)porphyrin $\left[\mathrm{Co}(\mathrm{II}) \mathrm{T}\left(\mathrm{pNH}_{2}\right) \mathrm{PP}\right]$, attached via amide bonding to a glassy carbon surface ${ }^{8 \mathbf{a}}$ (Fig. 9). The cyclic

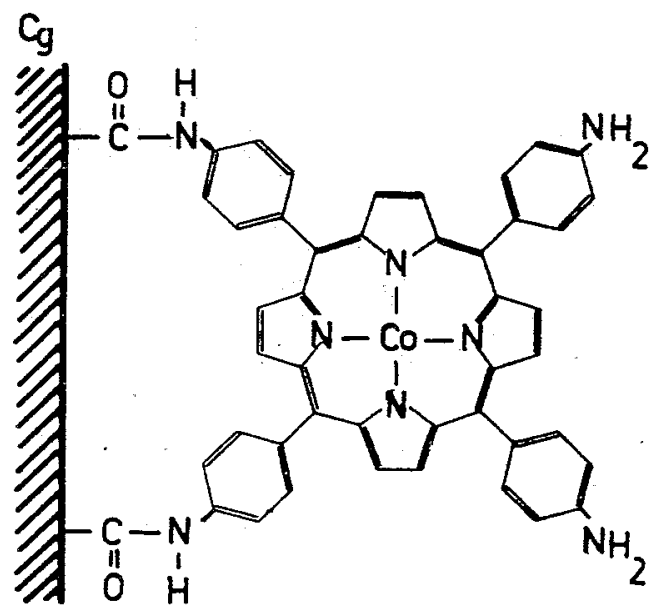

Fig. 9. $\mathrm{Co}(\mathrm{II}) \mathrm{T}\left(\mathrm{pN \textrm {N } _ { 2 }}\right) \mathrm{PP}$ attached to the glassy carbon (Cg) surface via covalent bonding. 

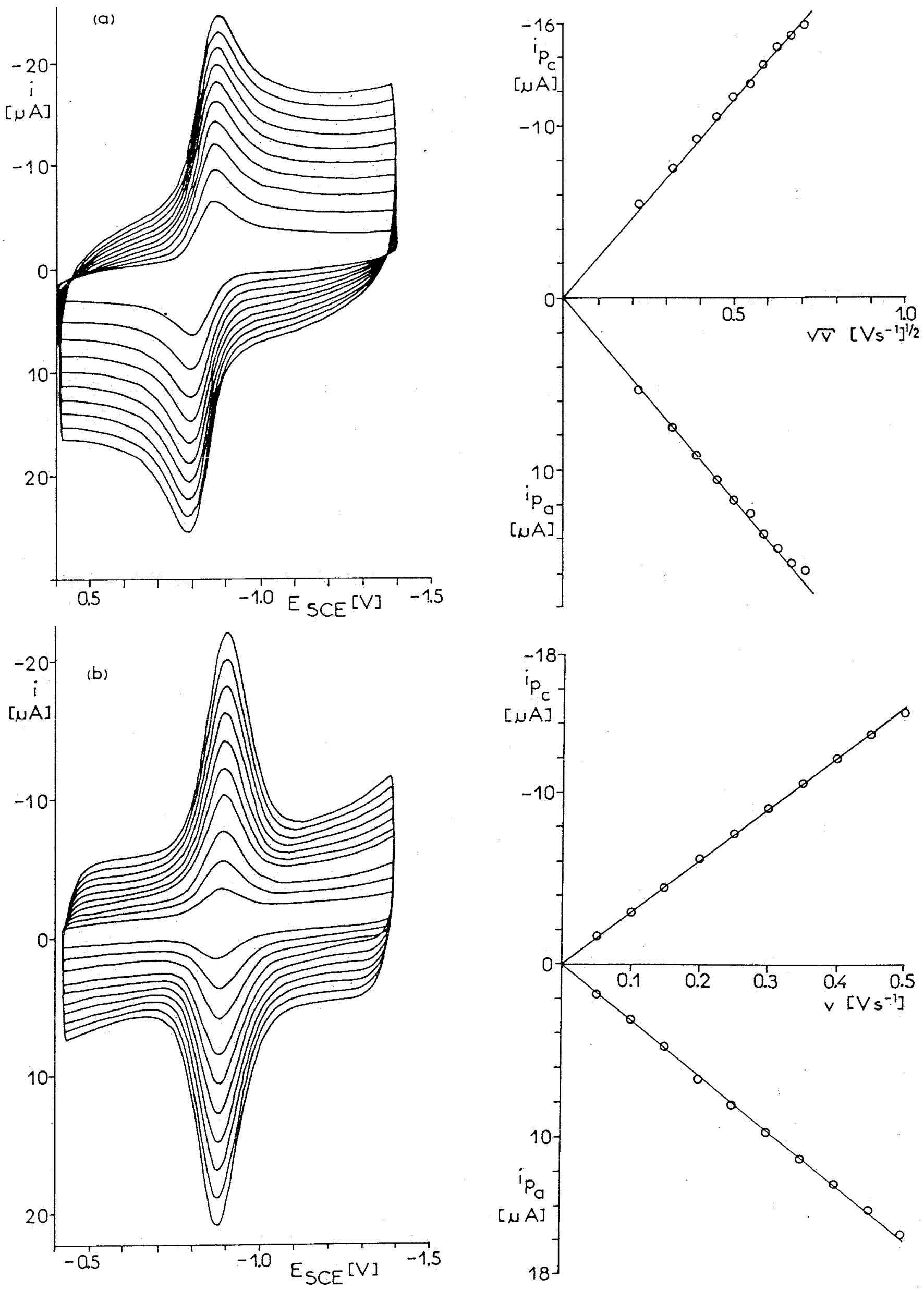

Fig. 10. Cyclic voltammograms of $\mathrm{CoT}\left(\mathrm{pNH}_{2}\right) \mathrm{PP}$ :

a) measured in solution at a $\mathrm{Cg}$ electrode and;

b) covalently bonded to the Cg electrode surface, for different potential scan rates $(v)$.

The dependence of the anodic and cathodic peak currents $\left(i_{\mathrm{p}}\right)$ upon $v$ are shown on the right-hand side of the figures. Experimental conditions: $v=0.05,0.10,0.15,0.20,0.25,0.30,0.35,0.40,0.45$ and $0.50 \mathrm{~V} \cdot \mathrm{s}^{-1}$. Measured in $0.1 \mathrm{M}$ TEAP/DMSO. 
voltammograms of the $\mathrm{Co}(\mathrm{II}) \mathrm{P} \rightleftarrows \mathrm{Co}(\mathrm{I}) \mathrm{P}$ reaction in solution and at the surface are shown in Figs. 10a and $b$, respectively. The characteristic differences are clearly shown. Most striking is the symmetrical peak shape and the linear dependence of the peak current $\left(i_{\mathrm{p}}\right)$ with the potential scan rate $(v)$, both characteristic of immobilized species. From the peak area in the cyclic voltamogram, a surface coverage of $1.8 \cdot 10^{-10} \mathrm{~mol} \cdot \mathrm{cm}^{-2}$ is determined. This corresponds to $50 \%$ of a monolayer coverage*, if "edge-on" orientation of the porphyrin is assumed, and to 1.5 times a monolayer, if all porphyrin molecules are orientated "face-down". Rocklin ${ }^{30}$ determined from XPS measurements an average of two amide bonds between a porphyrin molecule and the glassy carbon surface, thus both orientations of the porphyrin will be present. A surface concentration of $1.8 \cdot 10^{-10} \mathrm{~mol} \cdot \mathrm{cm}^{-2}$, found for $\mathrm{T}\left(\mathrm{pNH}_{2}\right) \mathrm{PP}$, can therefore quite easily correspond to a monolayer coverage. This high surface concentration could only be obtained after oxygen rf-plasma treatment. If the glassy carbon was pretreated by an Ar plasma and subsequently reacted with oxygen at low temperatures, then only a few percent of a monolayer coverage was obtained. Obviously, the $\mathrm{O}_{2}$ plasma creates more carboxylic acid groups. The reaction of molecular oxygen with an Ar plasma treated glassy carbon surface probably does not allow formation of carboxylic surface groups.

It is, however, impossible to detect directly the carboxylic surface groups by electrochemical techniques. Similarly, using Raman, XPS and SIMS, no unambiguous identification of the carboxyl group could be obtained. The quinone surface groups, however, were readily detected by phase-selective ac-voltammetry and chemical derivatization $^{58}$

The non-ideal behaviour of immobilized redox systems is reflected in a broadened peak with respect to the ideal reversible case. In the latter case, the peak width at mid-height $\left(W_{\frac{1}{2}}\right)$ is $90.6 / \mathrm{n} \mathrm{mV}$. As can be seen in Fig. $10 \mathrm{~b}, W_{\frac{1}{2}}$ is more than $130 \mathrm{mV}$ for the redox peaks of the Co(II) $\mathrm{T}^{2}-$ $\left(\mathrm{pNH}_{2}\right)$ PP-modified glassy carbon electrode. The theory described above accounts for the peak broadening by mutual interaction of the porphyrin molecules. In Table I, the interaction parameter $(r)$, calculated from Eq. 12 , is listed for several potential scan rates. Indeed, the calculated values for $W_{\frac{1}{2}}$ agree very well with those found experimentally.

The negative interaction parameter of about $-5.6 \cdot 10^{9}$ $\mathrm{cm}^{2} \cdot \mathrm{mol}^{-1}$ suggests a destabilizing interaction between the porphyrin molecules. Similar values have been reported in the literature for other immobilized redox species $^{59}$. Rather than comparing the $r$ values, it is more appropriate to compare the values of $r \Gamma_{\mathrm{T}}$, since these more correctly describe the effect on the electrochemical parameters such as peak current $\left(i_{\mathrm{p}}\right)$ and peak width $\left(W_{\frac{1}{2}}\right)$. For the phase-selective $\left(\lambda 90^{\circ}\right)$ ac-voltammogram of a $\mathrm{Co}(\mathrm{II}) \mathrm{T}\left(\mathrm{pNH}_{2}\right) \mathrm{PP}$-modified $\mathrm{Cg}$ electrode (Fig. 11), the calculated peak width $\left(W_{1}\right)$ of $179 \mathrm{mV}$ also agrees well with the $W_{\frac{1}{2}}$ of $172 \mathrm{mV}$, determined from the voltammogram. From comparison of the experimental values of $W_{\frac{1}{2}}$ for different immobilized redox systems, $S m i t h^{3 n}$ found a practically linear correlation between $W_{\frac{1}{2}}$ and $r \Gamma_{\mathrm{T}}$.

\section{Enzyme-modified electrodes (EME)}

Electrocatalysis by (immobilized) systems such as porphyrins and phthalocyanines has received much attention.

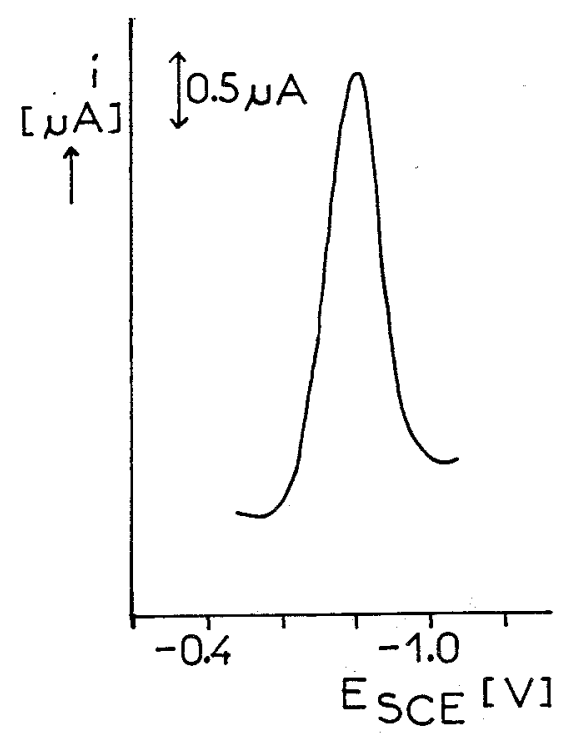

Fig. 11. The phase-selective ac-voltammogram of a $\mathrm{CoT}\left(\mathrm{pNH}_{2}\right)$ PP-modified glassy carbon electrode. Experimental conditions: $\lambda=90^{\circ}, \varepsilon=10 \mathrm{mV}$ (rms), $\omega=20 \mathrm{~s}^{-1}, v=0.01 \mathrm{~V} \cdot \mathrm{s}^{-1}, 0.1 \mathrm{M} T E A P / D M S O$.

These catalysts are called "synzymes", i.e. synthetic enzymes. However, such a system is only a reduced copy of the prosthetic group of the enzyme, and properties such as specificity or activity, inherent in the enzyme, are partly lost. On the other hand, the synzymes often catalyze reactions different from the substrate reaction of the enzyme. Only recently has the enzyme as a whole been immobilized on a bare electrode surface, with the desired properties being retained. In particular, properties such as high activity (with turn-over numbers of $10^{2}-10^{8}$ $\mathrm{M}^{-1} \cdot \mathrm{s}^{-1}$ ) and directly specificity make enzymes very attractive for application in electrochemistry. The enzyme (ع) can be active in solution or at the electrode surface, but usually a mediator (M) is necessary for electron transfer (Fig. 12). Of course, direct electron transfer to the immobilized enzyme is preferred. In this case, however, only redox enzymes can be used.
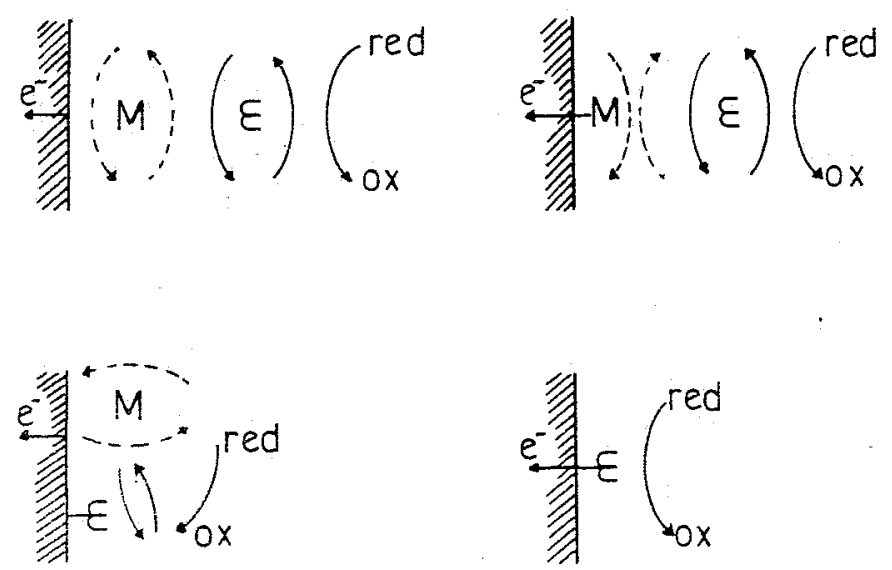

Fig. 12. Possible electron transfer pathways from substrate to enzyme (to mediator) to electrode and vice versa.

$M=$ mediator,$\varepsilon=$ enzyme.
* If, for the $\mathrm{T}\left(\mathrm{pNH}_{2}\right) \mathrm{PP}$ molecule, an approximate volume of $12 \AA \times 12 \AA \times 4 \AA$ is used, then about $3.5 \cdot 10^{-10} \mathrm{~mol} \cdot \mathrm{cm}^{-2}$ can be orientated "edge-on" or about $1.2 \cdot 10^{-10} \mathrm{~mol} \cdot \mathrm{cm}^{-2}$ can be orientated "face-down".

\footnotetext{
58a $J$. Schreurs and E. Barendrecht, to be published.

${ }^{\mathrm{b}} \mathrm{See}$ also ref. $8 \mathrm{a}$.
}

59 See refs. $31,3 n, 5 a$ and $13 b$. 
The advantages of immobilizing enzymes have been recognized for many years, e.g. in chromatography. In addition to the usual advantages, such as repetitive use of a single batch, ability to readily remove the enzyme from the reaction mixture, etc., the stability of the enzyme is also increased by immobilization. However, there are differences with respect to the solution-phase enzyme; resulting from steric orientation, rate-limiting mass transport and other microenvironmental effects, such as accessibility. The most important is probably the steric orientation of the enzyme at the electrode surface. The catalytic activity will be reduced if the active site of the enzyme is partially or totally blocked by the support or if an inactive conformation is formed. The active site of the enzyme must therefore be directed to the solution phase, thereby facilitating the substrate reaction. The area opposite to the active site must, in addition, be accessible for electron transfer. However, electron transfer to enzymes, under physiological conditions, is a very specific and complicated process, accomplished, for example, by redox proteins interacting at distinct sites in the enzyme. The electron transfer from electrode to enzyme, and vice versa, will therefore, in the case of immobilized as well as free enzymes, occur in the solution phase.

\section{Immobilization techniques}

Techniques for immobilization of enzymes have been extensively described in the literature ${ }^{60}$, and will therefore be treated here only within the scope of possible electrochemical applications. Three main immobilization techniques can be distinguished, see Fig. 13. The physical entrapment of an enzyme within a polymeric matrix (e.g. polyacrylamide) would be promising for polymer-film-modified electrodes. The enzyme can also be regarded as a monomer, possessing several functional groups, suitable for polymerization (cross-linking) at an electrode surface. In this case, however, certain effects may inhibit electron transfer, and loss of the activity of the enzyme may occur.
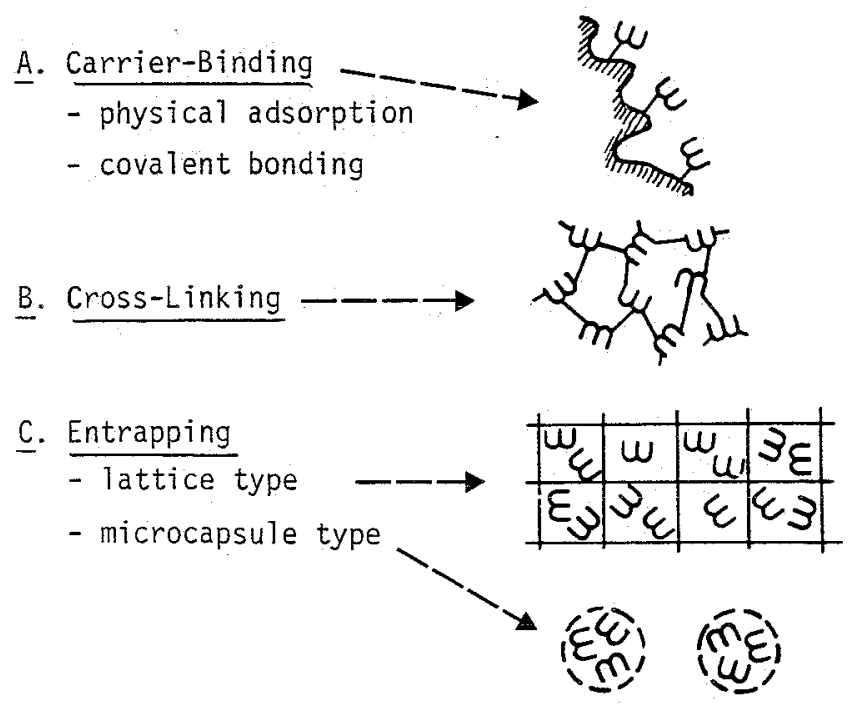

Fig. 13. Procedure for immobilization of enzymes.

A relatively simple technique, which in most cases retains the activity of the enzyme, is adsorption at the bare electrode surface. The major disadvantage, of course, is possible desorption.

Covalent bonding of enzymes to an electron-conducting carrier is the technique most frequently associated with the term "immobilized enzymes". This technique not only modifies the electrode surface (carrier), but also includes a chemical modification of the enzyme, which may result in a decrease in activity. Protein surface groups, which are near the active site of the enzyme, or form part of it, should therefore not participate in the covalent bonding. As might be expected, the type of immobilization technique used has a strong effect on the utility of the system. For electrochemical purposes, the situation where the enzymes are covalently attached to the electrode surface is preferred. At the protein surface of enzymes, several reactive groups are present which can be used for covalent bonding, e.g. amino, carboxyl, hydroxyl, mercapto, etc.

From the amino-acid composition ${ }^{61}$ of the enzymes, the most abundantly present reactive functional groups can be deduced. However, not all of these groups are located at or near the protein surface, and are not therefore available for covalent bonding. Knowledge of the three-dimensional structure of the enzyme is thus valuable for identifying where the active site and the functional groups at the surface are located.

\section{Covalent bonding to a glassy carbon electrode surface}

For covalent bonding to a glassy carbon surface, carboxyl as well as amino groups at the protein surface are suitable with ester and amide bonding resulting from the reaction with the hydroxyl and the carboxyl group of the carbon surface, respectively. The reaction is accomplished via a coupling reagent, namely, 1-cyclohexyl-3-(2-morpholinoethyl)carbodiimide metho- $p$-toluenesulfonate (CMC), which cannot be added to the enzyme solution, since this would lead to cross-linking. The glassy carbon electrode is therefore pretreated with the reagent and subsequently reacted with the enzyme in solution. Elucidation of the true nature of the chemical bond (ester or amide) is very difficult because of the very complex protein structure (containing numerous amide bondings) present at the electrode surface. However, the enzyme, once attached by this procedure, can then not be removed using methods normally applied to adsorbed species (i.e. washing with highly concentrated salt solutions), thus implying that covalent bonding has occurred.

The enzyme glucose oxidase* and the redox protein cytochrome-c $3^{* *}$, for example, have been attached to the glassy carbon surface using the procedure described above. The cyclic voltammogram of glucose oxidase immobilized at a glassy carbon electrode is shown in Fig. 14. The peak potential $(-0.49 \mathrm{~V})$ is more cathodic than the redox potential of glucose oxidase $(-0.38 \quad \mathrm{~V})^{62 \mathrm{a}}$ and agrees very well with the redox potential of free $F A D$ $(-0.485 \mathrm{~V})^{62 \mathrm{~b}}$. The idea was to replace the electron ac-

* Glucose oxidase contains two flavine adenine dinucleotide (FAD) groups, tightly bound to the protein ( $M 186000)$, and catalyzes the oxidation of glucose to gluconic acid, using oxygen as an electron acceptor $\left(\mathrm{O}_{2} \rightarrow \mathrm{H}_{2} \mathrm{O}_{2}\right)$.

** Cytochrome-c3 contains four heme groups (M 14000$)$, covalently attached via thio-ether bridges to a polypeptide chain of 107 amino acids, and functions as an electron carrier for hydrogenase in sulfate-reducing bacteria.

${ }^{60 a}$ S. J. Gutcho, "Immobilized Enzymes", Chemical Technology Review No. 39. Noyes Data Corporation, London, England (1974).

b"Immobilized Enzymes", Ed. K. Mosbach, Methods in Enzymology, Vol. XLIV.

${ }^{c}$ L. D. Bowers and P.W. Carr, "Immobilized Enzymes in Analytical Chemistry", Advances in Biochemical Engineering, vol. 15.

'O.R. Zaborsky, "Immobilized Enzymes", CRC-Press (1974). 61 See, for example, the Handbook of Biochemistry.

${ }^{62 \mathrm{a}}$ T. Ikeda, S. Ando and M. Senda, Bull. Chem. Soc. Jpn. 54, 2189 (1981)

${ }^{\mathrm{b}}$ F. Scheller, G. Strnad, B. Neumann, M. Kühn and W. Ostrowski, Bioelectrochem. Bioenerg. 6, 117 (1979), 


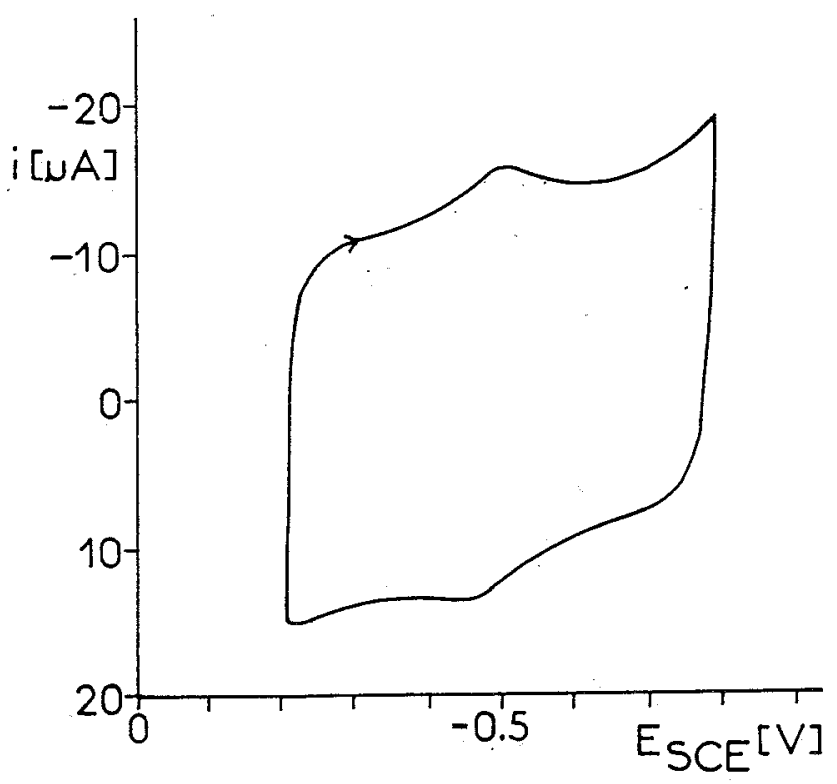

Fig. 14. Cyclic voltammogram $\left(v=0.5 \mathrm{~V} \cdot \mathrm{s}^{-1}\right)$ of glucose oxidase, attached to a glassy carbon electrode.

ceptor, oxygen, by the electrode and thus be in a position to continuously regenerate the enzyme for oxidation of glucose. However, addition of glucose to the solution had no effect on the electrochemical behaviour of immobilized glucose oxidase. The glucose oxidase, obviously, has lost its activity upon immobilization, probably due to a change in the protein conformation, resulting in its influence on the redox potential of the FAD group being lost; hence the good agreement between the measured peak potential and the redox potential of free FED.

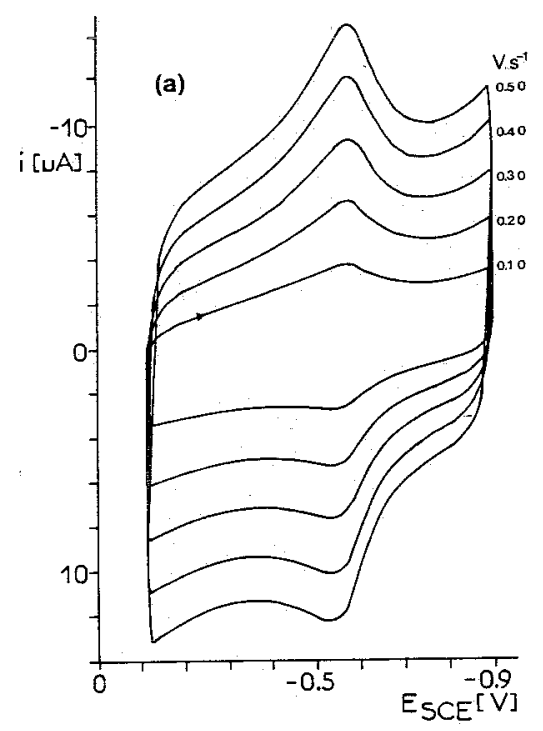

(b)

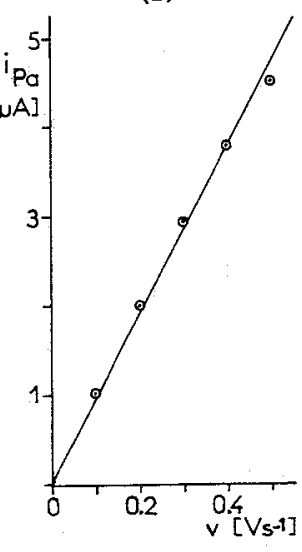

Fig. 15. a) Cyclic voltammograms of cytochrome-3, attached to a glassy carbon electrode, for differential potential scan rates.

b) Plot of the anodic peak current $\left(i_{\mathrm{p}_{\mathbf{a}}}\right)$ vs. the potential scan rate $(v)$.

The cyclic voltammograms of the redox protein cytochrome-c3 (D. Vulgaris, Hildenborough), attached to a glassy carbon electrode surface, are shown in Fig. 15. Only one redox peak, at $-0.56 \mathrm{~V}$, is observed. The peak current $\left(i_{\mathrm{p}}\right)$, as well as the peak area $\left(Q^{\prime}\right)$, are linearly dependent upon the potential scan rate $(v)$, as is characteristic for immobilized species. The peak at $-0.56 \mathrm{~V}$ is broadened because the redox potentials of the four heme groups in cytochrome-c3 are inequivalent ${ }^{63}$. The peak potential
$(-0.56 \mathrm{~V})$ agrees very well with the half-wave potential $\left(E_{\frac{1}{2}}-0.55 \mathrm{~V}\right)$ of cytochrome-c3 in solution, measured at a glassy carbon electrode, and with the half-wave potential $\left(E_{\frac{1}{2}}-0.57 \mathrm{~V}\right)$, measured at a mercury electrode. A quasi-reversible behaviour of cytochrome-c3 is observed at most electrode materials, probably due to the ready accessibility of the four heme groups.

Thus, immobilization of certain enzymes at a glassy carbon electrode surface, via dehydrative coupling with $\mathrm{CMC}$, has been shown to be possible. The major problem, however, is to obtain a suitable interface for direct electron transfer between electrode and enzyme. The observed resistance of the enzyme to reduction or oxidation is to be expected, since, under physiological conditions, specific interactions are required between enzyme and electron carrier in order to obtain effective electron transfer. We therefore initiated an investigation into the possible features, such as protein charge, which might contribute to the specific interaction between enzyme and electrode. Several redox proteins (ferredoxins, flavodoxins, etc.) in solution were measured at the dropping mercury electrode $(\mathrm{DME})^{64}$. Compensation of the protein charge increased the reduction efficiency, for the ferredoxins, even to $100 \%$. The electrochemical behaviour of cytochrome-c at a gold and at a platinum electrode, in the presence of 4,4'-bipyridine, was also studied ${ }^{65}$ and it was found that cytochrome-c strongly adsorbs at both the platinum and the gold electrode.

\section{Applications of SME}

Possible applications of SME are numerous, which is one of the reasons why much attention has been focused on surface-modified electrodes. As shown above, electrode surfaces can be tailor-made, which allows electrochemical reactions to be catalyzed in both a reactive and a specific sense. Applications are to be found in the field of electrosynthesis (stereospecific reactions, for exampie), electroanalysis (sensors), electrocatalysis (energy conversion) and photo-electrocatalysis. Applications of enzyme-modified-electrodes (EME) are also found in these fields. Hitherto, mostly membrane(polymer)-immobilized enzymes have been used with the bare electrode (usually platinum) merely functioning as an indicator electrode for the product ${ }^{66}$. There are only a few examples of EME's, where the enzyme is attached in some way to the bare electrode surface and direct electron transfer from the electrode to the enzyme occurs.

${ }^{63 a}$ P. Bianco, G. Fauque and J. Haladjian, Bioelectrochem. Bioenerg. 6, 385 (1979).

${ }^{b} P$. Bianco and $J$. Haladjian, Electrochim. Acta 26, 1001 (1981).

c P. Bianco and J. Haladjian, J. Electroanal. Chem. 137, 367 (1982).

d W.F. Sokol, D. H. Evans, K. Niki and T. Yagi, ibid. 108, 107 (1980).

' K. Niki, T. Yagi, H. Inokuchi and K. Kimura, J. Am. Chem. Soc. 101, 3335 (1979).

f M.J. Eddowes, H. Elzanowska and H. A.O. Hill, Biochemical Society Transactions 582nd. Meeting, St. Andrews, Vol. 7, p. 735 .

64 C. van Dijk, J. W. van Leeuwen, C. Veeger, J. P. G. M. Schreurs and E. Barendrecht, Bioelectrochem. Bioenerg. 9, 743 (1982).

65 J. Schreurs and E. Barendrecht, to be published.

66 $K$. Cammann, Z. Anal. Chem. 287, 1 (1977). 

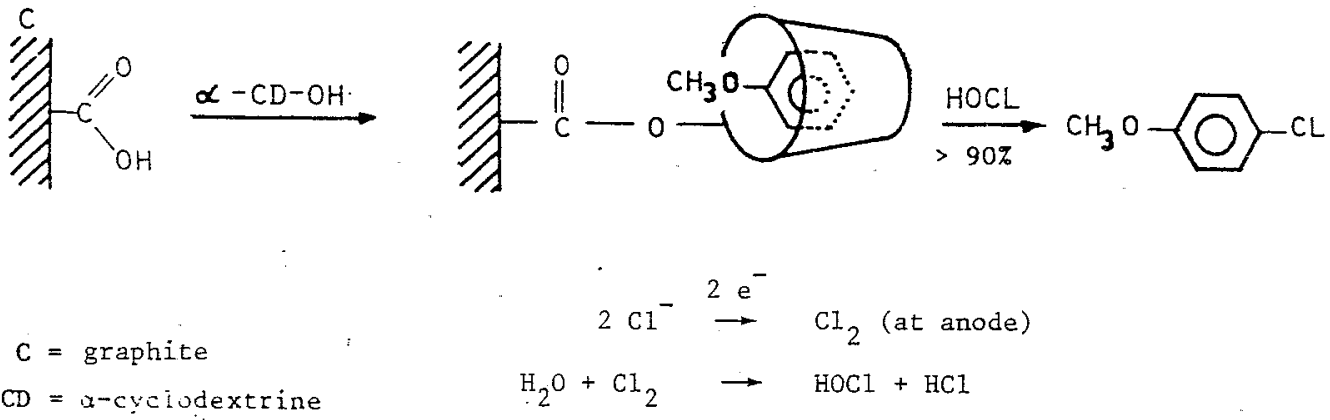

$\mathrm{CD}=x$-cyciodextrine

Fig. 16. Selective chlorination of anisole at an $\alpha$-cyclodextrin-modified graphite electrode ${ }^{67}$.

\section{Electrosynthesis}

The first report on surface-modified electrodes, by Miller $^{2}$, was an example of chiral induction. Optically active alcohols were synthesized at a graphite electrode, modified with covalently bonded optically active $(S)-(-)$-phenylalanine methyl ester. At this electrode, asymmetric synthesis of sulfoxides was also possible. $\mathrm{Os}^{67}$ has reported the selective chlorination of anisole at a cyclodextrin-modified graphite electrode. The anisole fitted exactly into the cyclodextrin cavity (Fig. 16) which protected the $o$-position from chlorination; a para/ortho ratio of $18 / 1$ was obtained. At a metal (Mo, W) electrode, modified with 1,2-bis(diphenylphosphino)ethane $\left[\mathrm{M}(\mathrm{dppe})_{2}\right]$, complexation of dinitrogen occurs, which can then be reduced and converted into an organic nitrogen compound ${ }^{68}$. The electroorganic synthesis of expensive pharmaceuticals may also provide an application of modified electrodes, in particular of enzyme-modified electrodes. Stereospecific reactions, for example, are readily performed by enzymes ${ }^{69}$. A very important reaction is the regeneration of coenzymes. EME's are certainly worthy of exploitation in this regard: e.g. electrode modified with ferredoxin: NADP oxido reductase ${ }^{70}$.

\section{Electroanalysis}

Lane and Hubbard $d^{71}$ developed an iodide-modified platinum electrode for quantitative (in vivo) electrochemical detection of catecholamines in brain tissue (Fig. 17).

\section{,}

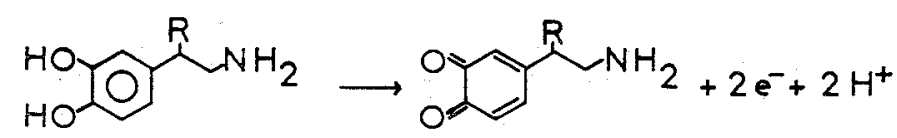

Fig. 17. Iodide-modified platinum electrode (chemisorbed) for quantitative (in vivo) detection of catecholamines in brain tissue $^{71}$. Dopamine $(R=H)$ and norepinephrine $(R=O H)$.

Catecholamines (dopamine, norepinephrine) are essential participants in the neurotransmission process. Poly(4 -vinylpyridine)-modified electrodes (Fig. 6) are very suitable for the detection of metal ions at a low concentration level (up to $5 \times 10^{-8} \mathrm{M}$ ) ${ }^{45 a}$, and can therefore be useful in the analysis of polluted water, etc. Carbon-paste electrodes, modified with diethylenetriamine, "can be applied to the analysis of the silver ions in aqueous media ${ }^{72}$, even down to concentrations in the picomolar region.
The poly(1,2-diaminobenzene)coated platinum electrode exhibits an almost Nernstian response to changes in the $\mathrm{pH}$ and can therefore be used as a potentiometric sensor ${ }^{73}$. In aprotic media (e.g. acetonitrile), a poly(vinylferrocene)-modified platinum electrode ${ }^{51 a}$ can be used as reference electrode, thus avoiding concentration-dependent liquid-junction potentials. The high selectivity and sensitivity render modified electrodes very suitable to in vivo analysis. EME's in particular are, of course, the most appropriate electrodes in this respect. Electrodes modified with glucose oxidase, which function as a glucose sensor, have been extensively investigated ${ }^{74}$.

\section{Electrocatalysis (energy conversion)}

Modification of electrode surfaces by catalysts adds an extra dimension to the scope of electrocatalysis. The modified electrode can act as a redox catalytic system. For example, metal-phthalocyanine-modified pyrolytic graphite electrodes catalyze the oxidation of hydrazine $^{31, k, m}$ and cysteine ${ }^{3 \text { if }}$, while a cobalt-porphyrin-modified carbon electrode, in contrast to the bare electrode, readily reduces 1,2 -dibromophenylethane $\left(\mathrm{C}_{6} \mathrm{H}_{5}-\right.$ $\left.\mathrm{CHBrCH}_{2} \mathrm{Br}\right)^{11 i}$. The reduction of horse-heart cytochrome-c is catalyzed by a poly(vinylviologen)-modified electrode $^{49}$. In view of the application in fuel cells, the catalytic reduction of dioxygen to water is being intensively studied. This reduction can also be catalyzed by several types of modified electrodes ${ }^{75}$. In Fig. 18, the reduction of

${ }^{67 a}$ T. Matsue, M. Fujihira and T. Osa, J. Electrochem. Soc. 126, 500 (1979).

${ }^{\mathrm{b}}$ T. Matsue, M. Fujihira and T. Lsa, Bull. Chem. Soc. Jpn. 52, 3692 (1979).

68 G.J. Leigh and C.J. Pickett, J. Chem. Soc. Dalton 1797 (1977).

69 G. Popjak in "The Enzymes", Ed. Boyer, vol. 2, chapter 3.

${ }^{70}$ R. Dilosimo, C. H. Wong, L. Daniels and G.M. Whitesides, J. Org. Chem. 46, 4623 (1981)

${ }^{71 a}$ R. F. Lane, A.T. Hubbard, K. Fukunaga and R.J. Blanchard Brain Research 114, 346 (1976).

${ }^{\mathrm{b}}$ R. F. Lane and A. T. Hubbard, Anal. Chem. 48, 1287 (1976).

${ }_{72}$ G. T. Cheek and R. F. Nelson, Anal. Lett. 11, 393 (1978).

73 W. R. Heineman, H.J. Wieck and A. M. Yacynych, Anal. Chem. 52, 345 (1980).

${ }^{74 a}$ F. R. Shu and G. S. Wilson, Anal. Chem. 48, 1679 (1976)

${ }^{b}$ R. A. Kamin and G. S. Wilson, ibid. 52, 1198 (1980).

${ }^{75 a}$ See also refs. $31 \mathrm{c}, \mathrm{j}, 46 \mathrm{a}$ and $49 \mathrm{~d}$.

${ }^{b}$ J. P. Collman, P. Denisevich, Y. Konai, M. Marocco, C. Koval and F.C. Anson, J. Am. Chem. Soc. 102, 6027 (1980).

${ }^{c} J$. Zagal, P. Bindra and E. Yeager, J. Electrochem. Soc. 127, $1506(1980)$.

dJ. P. Collman, F. C. Anson, C. E. Barnes, C. Susana Bencosme, T. Geiger, E. R. Evitt, R. P. Kreh, K. Meier and R. B. Pettman, J. Am. Chem. Soc. 105, 2694 (1983).

' J. P. Collman, C. Susana Bencosme, R. R. Durand, R. P. Kreh and F. C. Anson, ibid. 105, 2699 (1983).

${ }^{\mathrm{f}}$ R. R. Durand, C. Susana Bencosme, J.P. Collman and F. C. Anson, ibid. 105, 2710 (1983) 

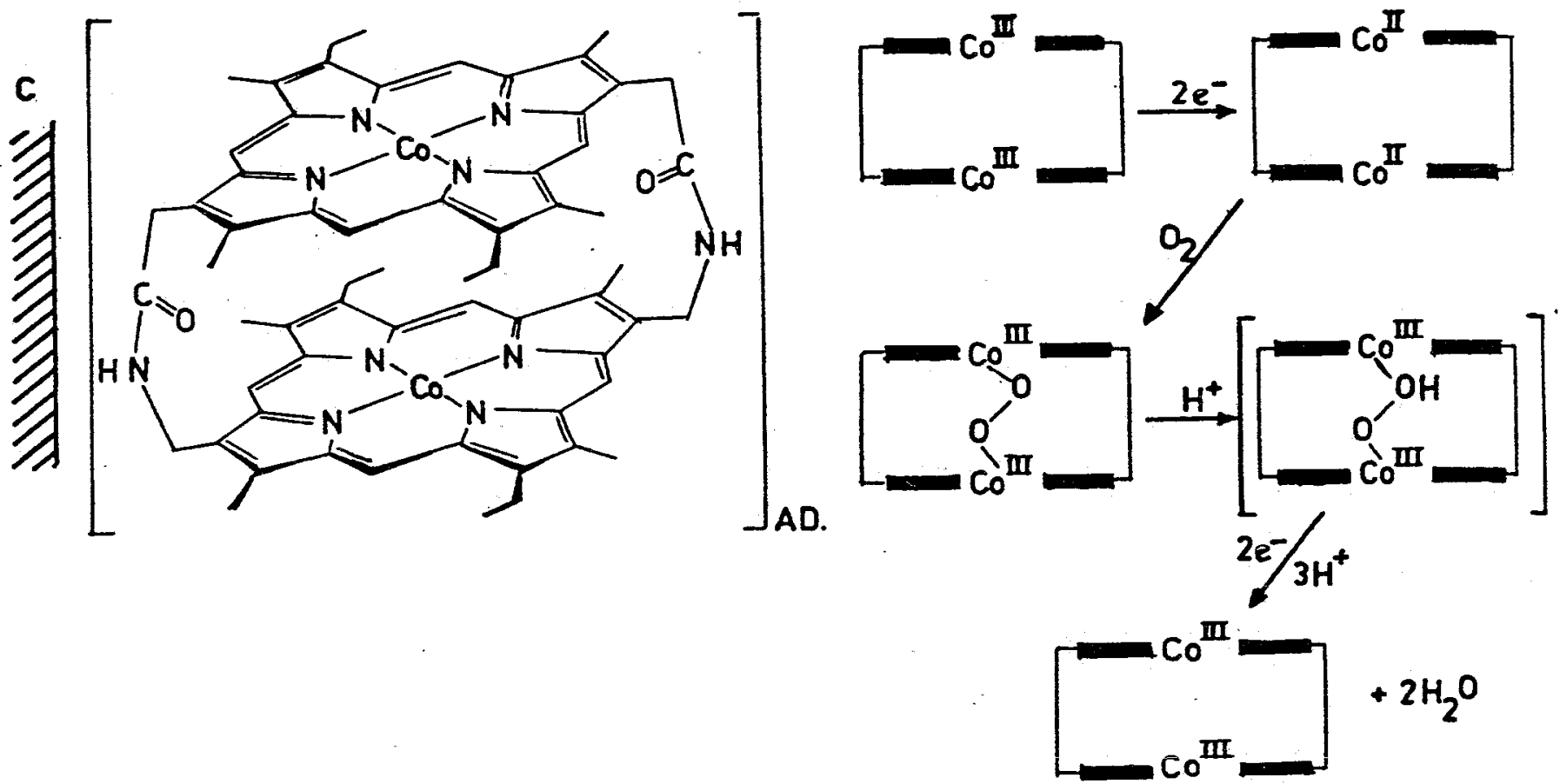

Fig. 18. Catalytic reduction of dioxygen to water at a dicobalt face-to-face porphyrin-modified graphite electrode ${ }^{75}$.

dioxygen to water is shown at a dicobalt face-to-face porphyrin-modified graphite electrode. Maintaining the proper distance between the cobalt sites is very important in order to prevent reduction to hydrogen peroxide. A mechanistic study of metal phthalocyanines as electrocatalysts for oxygen reduction has recently been published ${ }^{76}$. At an iron-phthalocyanine-modified electrode, the main reaction is a direct reduction of oxygen to water, while for cobalt phthalocyanine, the reduction product is mainly hydrogen peroxide.

A very interesting example is the catalyzed reduction of oxygen to water at a laccase-modified (via adsorption) carbon electrode ${ }^{77}$. The reduction takes place at $1.21 \mathrm{~V}$, which is very close to the oxygen standard potential $(1.23 \mathrm{~V})$. A high exchange current density is also observed, even though the activity of immobilized laccase is only $4 \%$ of its activity in solution. In the presence of hydrogenase, oxidation of hydrogen occurs at carbon electrodes at a potential, and with an exchange current density, close to that measured for platinum electrodes ${ }^{78}$. In the context of energy conversion it would be very interesting to apply the enzymes cytochrome-c oxidase ${ }^{79}$ and hydrogenase ${ }^{78}$ as EME for catalyzing the reduction of oxygen and the oxidation of hydrogen, respectively.

\section{Photo-electrocatalysis}

The efficiency of solar energy conversion by photo-electrodes can be improved by modification -with appropriate dyes such as phthalocyanine, erythrosine, rhodamine-B, etc. ${ }^{80}$. The photosensitivity of the electrode is thereby shifted from the UV towards the visible region. This process is called sensitization. The stability of the photo-electrodes in aqueous solutions is improved by modification with these dyes or, for example, with trimethylchlorosilane ${ }^{18 c}$. An increase in the photocurrent density can be achieved by increasing the dye surface concentration. The photo-assisted electrochemicăl ôxidartion of isopropanol to acetone was catalyzed at a 2-aminoanthraquinone-modified carbon electrode ${ }^{12 c}$, while a photo-assisted hydrogen evolution is achieved at a poly(benzylviologen)-modified $p$-type $\mathrm{Si}$ electrode ${ }^{49 \mathrm{a}}$. Wrighton $^{81}$ modified $\mathrm{Pt}, \mathrm{Au}$ and $p-\mathrm{Si}$ electrodes with $N, N^{\prime}$-bis [3-(trimethylsilyl)propy1]-4,4'-bipyridinium di- bromide in which the bromide anion is exchangeable with $\mathrm{Cl}^{-}, \mathrm{ClO}_{4}{ }^{-}, \mathrm{SO}_{4}^{2-}$, but also with $\mathrm{Ru}-, \mathrm{Co}-, \mathrm{Mn}$-cyanide and Pt- or Pd-chloride. A surface system such as $\left[\left(\mathrm{PQ}^{2+/+}\right)_{n}-n \mathrm{Pt}(0)\right]$ (Fig. 19) is obtained by photoreduction of $\mathrm{PtCl}_{6}^{2-}$ to $\mathrm{Pt}(0)$, with the result that $\mathrm{Pt}$ (but also $P d)$ are dispersed in the polymer. Such a modified electrode yields an improved hydrogen evolution and an optimum $\mathrm{pH}$ for catalysis exists, consistent with the $\mathrm{pH}$ independent formal potential of the $\left(\mathrm{PQ}^{2+1+}\right)$ redox

${ }^{76}$ F.T. B.J. van den Brink, Thesis, Eindhoven University of Technology, The Netherlands.

${ }^{77 a}$ M. R. Tarasevich, A.I. Yaropolov, V.A. Bogdanovskaya and S. D. Varfolomeev, Bioelectrochem. Bioenerg. 6, 393 (1979).

${ }^{b} I$. V.: Berezin, V.A. Bogdanovskaya, S. D. Varfolomeev, M.R. Tarasevich and A.I. Yaropolov, Dikl. Phys. Chem. 240, 455 (1978).

78 I. V. Berezin, S.D. Varfolomeev, A.I. Yaropolov, V.A. Bogdanovskaya and M. R. Tarasevich, Dikl. Phys. Chem. 225, 1141 (1975).

${ }^{79 a}$ BO. G. Malmström, Quart. Rev. Biophys. 6, 389 (1974).

${ }^{b}$ BO. G. Malmström in "Metal Ion Activation of Dioxygen by T. G. Spiro.

${ }^{80 \mathrm{a}}$ See also refs. $18 \mathrm{c}, 19$ and 200 .

${ }^{\mathrm{b}}$ A. Hamnet, M. P. Dare-Edwards, R. D. Wright, R. R. Seddon and J. B. Goodenough, J. Phys. Chem. 83, 3280 (1979).

${ }^{\circ} T$. Yamase, H. Gerischer, M. Lubke and B. Pettinger, Ber. Bunsenges. Phys. Chem. 83, 658 (1979).

d F. F. Fan and A.J. Bard, J. Am. Chem. Soc. 101, 6139 (1979).

- T. Takizawa, T. Sawada, H. Kanada, A. Fujishima and K. Honda, J. Phys. Chem. 83, 658 (1979).

${ }^{f}$ T. Takizawa, T. Watanaba and K. Honda, J. Phys. Chem. 84, 51 (1980).

A. Girandeau, F. F. Fan and A. J. Bard, J. Am. Chem. Soc. 102, 5137 (1980).

${ }^{\text {h } C . D . ~ J a e g e r, ~ F . ~ F . ~ F a n ~ a n d ~ A . J . ~ B a r d, ~ i b i d . ~ 102, ~} 2592$ (1980). i T. M. Mezza, C. L. Linkous, V. R. Shepard, N. R. Armstrong, R. Nohr and M. Kenney, J. Electroanal. Chem. 124, 311 (1981).

j N. R. Armstrong and V.R. Shepard, Jr., ibid. 131, 113 (1982).

${ }^{81 \mathrm{a}}$ N.S. Lewis and M.S. Wrighton, Science 211, 944 (1981).

${ }^{b} J$. A. Bruce and M.S. Wrighton, J. Am. Chem. Soc. 4, 74 (1982).

' J. A. Bruce, T. Murahashi and M.S. Wrighton, J. Phys. Chem. 86, 1552 (1982) 
couple $(-0.55 \mathrm{~V}$ vs. SCE) and the $\mathrm{pH}$-dependent formal potential of the $\left(\mathrm{H}^{+} / \mathrm{H}_{2}\right)$ couple.

Electrodes modified with chlorophyll ${ }^{82}$ are the most suitable photo-electrocatalysts since photosynthesis is the most important process in plant life.

82 F. K. Fong and N. Winograd, J. Am. Chem. Soc. 98, 2287 (1976).
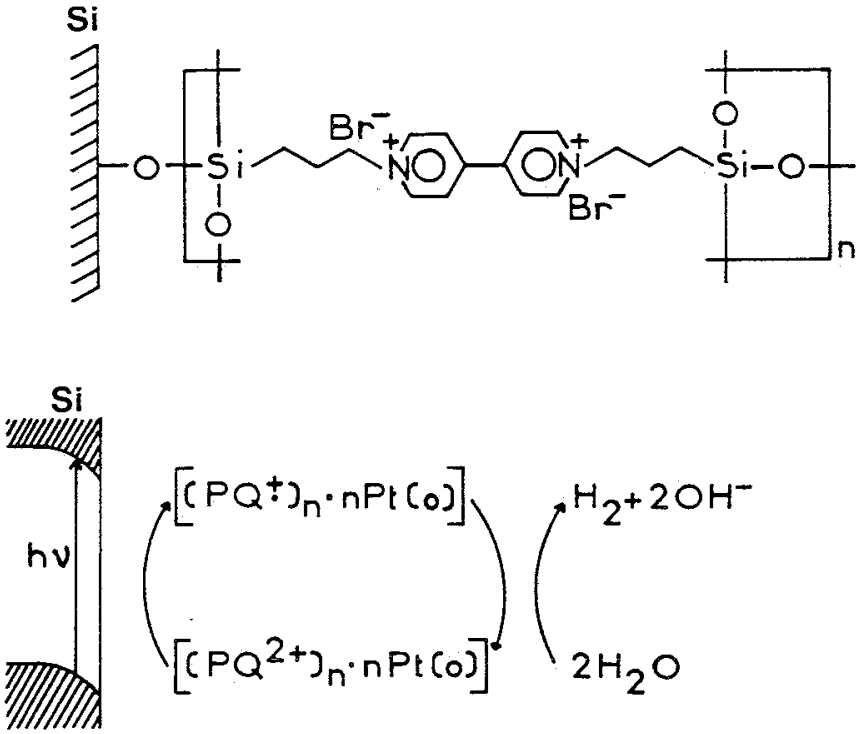

Fig. 19. Photo-assisted hydrogen evolution at a $\left[\left(\mathrm{PQ}^{2+1+\cdot}\right)_{n} \cdot n \mathrm{Pt}(0)\right]$-modified $p$-type silicon semi-conductor electrode ${ }^{6}{ }^{1}$.

$P Q=\mathrm{N}, \mathrm{N}^{\prime}$-bis[3-(trimethylsilyl)propyl]-4,4'-bipyridinium dibromide.

\section{Dutch Ph. D. Theses}

copies of the theses may be available at the supervisor's address

\section{PREPARATION AND PROPERTIES OF ULTRA-HIGH STRENGTH POLYETHYLENE FIBRES. June 1, 1984.}

\section{Jan Smook}

Supervisor: Prof. Dr. A.J. Pennings, Laboratory of Polymer Chemistry, State University Groningen.

The thesis describes a study on the preparation of ultra-strong polyethylene fibres by gel-spinning and hot-drawing, on their morphology, and on their melting befaviour and mechanical properties. Gel-spinning involves the processing of a semidilute solution of high molecular weight polyethylene $\left(\bar{M}_{w}=4 \times 10^{6}\right)$ in paraffin-oil into a continuous gel-filament. After extraction with n-hexane a porous fibre remains, which can be extensively drawn at elevated temperatures. The resulting highly oriented fibres can attain a tensile strength at break up to $5 \mathrm{GPa}$ and a Young's modulus of 160 $\mathrm{GPa}$.

The main objectives of the work were to elucidate the molecular mechanism underlying the fibre formation process and to clear up the discrepancy between the practical strength limit of the fibres of $5 \mathrm{GPa}$ and the theoretical strength of polyethylene, which amounts to $25 \mathrm{GPa}$.

Thesis written in English.
LITHIATION AND CARBOLITHIATION OF ALKENES AND ALKYNYLSILANES (May 18th, 1984)

KI_AAS J.H. KRUITHOF

Supervisor: Prof. dr. G.W. Klumpp, Department of Organic Chemistry, Free University Amsterdam.

A variety of novel cyclic products was obtained by anionic rearrangements of lithiated allylic ethers of syn-bicyclo[2.2.1] hept-2-en-7-ol and related compounds. The formation of all new products is consistent with a stepwise mechanism, the first step being an intramolecular type-I-lithium-ene reaction. The intermolecular carbolithiation of olefins by lithiated 3-methoxy-1-propene and the addition of trimethylsilyllithium to $\mathrm{C}=\mathrm{C}$ bonds were investigated. Carbolithiation of 3-trimethylsilylprop-2-yn-1-ols proceeded regio- and stereoselectively leading to vinylsilanes. Treatment of 2-alkynyl silyl ethers with $n$-butyllithium led to propargylic deprotonation solely. Depending on the reaction conditions, 1-alkynyl silyl carbinols and ( $\beta$-trimethylsilylvinyl)silyl ketones were obtained. Propargylic deprotonation was also observed upon reaction of alkyllithiums with 2-(1-alkynyl)-1,3-dioxanes. The lithium anionoids formed reacted with alkyl halides and related compounds under propargylic substitution exclusively. Addition to ketones gave mixtures of lithium alkynylcarbinolates and lithium allenylcarbinolates. The latter cyclized under mild conditions to $3-$ -lithio-2,5-dihydrofuran derivatives. Some unusual reactions of vinylsilanes are reported. Thesis written in English. 